\title{
Quantifying the spatial extent and intensity of recent extreme drought events in the Amazon rainforest and their impacts on the carbon cycle
}

Phillip Papastefanou ${ }^{1}$, Christian S. Zang ${ }^{1}$, Zlatan Angelov ${ }^{1}$, Aline Anderson de Castro ${ }^{2}$, Juan Carlos Jimenez ${ }^{3}$, Luiz Felipe 5 Campos De Rezende ${ }^{2}$, Romina Ruscica ${ }^{4,5,6}$, Boris Sakschewski ${ }^{7}$, Anna Sörensson ${ }^{4,5,6}$, Kirsten Thonicke ${ }^{7}$, Carolina Vera ${ }^{4,5,6}$, Nicolas Viovy ${ }^{8}$, Celso Von Randow² and Anja Rammig ${ }^{1}$

${ }^{1}$ Technical University of Munich, TUM School of Life Sciences Weihenstephan, Freising, Germany

${ }^{2}$ Earth System Sciences Centre, National Institute for Spatial Research, São José dos Campos, São Paulo, Brazil

${ }^{3}$ GCU/IPL, University of Valencia, Valencia. Spain.

$10{ }^{4}$ Universidad de Buenos Aires, Facultad de Ciencias Exactas y Naturales, Departamento de Ciencias de la Atmósfera y los Océanos. Buenos Aires, Argentina.

${ }^{5}$ CONICET - Universidad de Buenos Aires. Centro de Investigaciones del Mar y la Atmósfera (CIMA). Buenos Aires, Argentina.

${ }^{6}$ CNRS - IRD - CONICET - UBA. Instituto Franco-Argentino para el Estudio del Clima y sus Impactos (UMI 3351

15 IFAECI). Centro de Investigaciones del Mar y la Atmósfera (CIMA). Buenos Aires, Argentina.

${ }^{7}$ Potsdam Institute for Climate Impact Research (PIK), Telegraphenberg A31, Potsdam, 14473, Germany

${ }^{8}$ LSCE, CEA-CNRS-Univ Paris-Saclay, Saclay, France

20 Correspondence to: Phillip Papastefanou (papa@tum.de) 
https://doi.org/10.5194/bg-2020-425

Preprint. Discussion started: 2 December 2020

(c) Author(s) 2020. CC BY 4.0 License.

(c) (i)

Abstract. Over the last decades, the Amazon rainforest was hit by multiple severe drought events. Here we assess the severity and spatial extent of the extreme drought years 2005, 2010, and 2015/2016 in the Amazon region and their impacts on the carbon cycle. As an indicator of drought stress in the Amazon rainforest, we use the widely applied maximum cumulative water deficit $(\triangle \mathrm{MCWD})$. Evaluating an ensemble of ten state-of-the-art precipitation datasets for the Amazon region, we find that the spatial extent of the drought in 2005 ranges from 2.8 to 4.2 (mean $=3.2)$ million $\mathrm{km}^{2}(46-71 \%$ of the Amazon basin, mean $=53 \%)$ where $\triangle \mathrm{MCWD}$ indicates at least moderate drought conditions $(\triangle \mathrm{MCWD}$ anomaly $<25$ $\mathrm{mm}$ ). In 2010 , the affected area was about $16 \%$ larger, ranging from 3.1 up to 4.6 (mean $=3.7)$ million $\mathrm{km}^{2}(52-78 \%$, mean $=63 \%$ ). In 2016, the mean area affected by drought stress was similar to 2005 (mean $=3.2$ million $\mathrm{km}^{2} ; 55 \%$ of the Amazon

30 basin), but the general disagreement between data sets was larger, ranging from 2.4 up to 4.1 million $\mathrm{km}^{2}(40-70 \%)$. In addition, we compare differences and similarities among datasets using the self-calibrating Palmer Drought Severity Index (scPDSI) and a rainfall anomaly index (RAI). We find that scPDSI shows a much stronger, and RAI a much weaker drought impact in terms of extent and severity for 2016 compared to $\triangle \mathrm{MCWD}$. Using an empirical $\triangle \mathrm{MCWD}$-mortality relationship, we calculate biomass losses of the three drought events. We show that eight of ten datasets agree on biomass losses of about

$351.8 \mathrm{PgC}$ for the drought years 2005 and 2010, indicating that the more intense drought in 2005 equals a larger total area of the 2010 drought regarding biomass loss. For the 2015/2016 drought event, datasets show a large variability of biomass loss induced by drought stress ranging from 1.3 to $2.7 \mathrm{PgC}$ with a mean loss of $1.8 \mathrm{PgC}$. Disagreement across datasets increased, (1) when comparing the total area of more severe and extreme drought signals and (2) when comparing spatial drought location across datasets. Generally, only half of the datasets agreed on the location of a drought event. We conclude that for 40 deriving impacts of droughts to the Amazon Basin based on precipitation, an ensemble of datasets should be considered. This is especially relevant when assessing the impact of drought on the Amazon rainforest and its carbon cycle. 
https://doi.org/10.5194/bg-2020-425

Preprint. Discussion started: 2 December 2020

(c) Author(s) 2020. CC BY 4.0 License.

\section{(c) (i)}

\section{Introduction}

The severe drought events occurring in 2005, 2010 and 2015/16 in the Amazon basin are reasons for concern regarding their

frequency and severity, and their impacts on the Amazon rainforest. Different large-scale atmospheric processes related to increased sea surface temperature (SST) in the Pacific and the Atlantic Ocean seem to be responsible for such repeated mega-drought events (Coelho et al., 2012): While the drought 2015/16 was driven by a record-level El Niño event enhanced by the strong underlying global warming trend (Jimenez et al., 2018), the 2010 drought was a combination of a moderate El Niño event and anomalously warm SSTs in the tropical North Atlantic (Marengo \& Espinoza, 2016; Marengo et al., 2011).

50 Similarly, the 2005 drought was attributed to anomalies of warm SSTs in the North Atlantic (Marengo et al., 2008; Zeng et al., 2008). In consequence, such events differ in their strength, their timing and spatial patterns, and thus, impacted regions differ. While drought events related to El Niño events show a Southwest to Northeast gradient with dry conditions over the NE Amazon region (Malhi et al., 2008), drought events caused by anomalously warm North Atlantic SSTs show a NorthSouth gradient with dry conditions in the southern Amazon region (Lewis et al., 2011; Marengo et al., 2008). Even in the case of El Niño events, SSTs anomalies over the Eastern Pacific (EP) or the Central Pacific (CP) can lead to different impacts and spatial patterns of drought (Jimenez et al., 2019). In addition to their influence on temperature, recent El Niño events also showed amplified atmospheric vapor pressure deficit anomalies (Barkhordarian et al., 2019; Rifai et al., 2019). The impacts of such drought events on humid tropical forests, which are often not adapted to longer-lasting dryness, are severe. Increased forest mortality connected to drought events was observed in central and southern Amazonia (Lewis et al.,

60 2011; Phillips et al., 2009), as well as shifts in tree species composition (Esquivel-Muelbert et al., 2019). Droughts are assumed to be one of the main drivers for the observed decline in the Amazon carbon sink, indicating that more carbon is lost to the atmosphere than taken up by the forest (Hubau et al., 2020). Thus, such extreme drought events are altering the carbon cycle of the Amazon forest already today (Gloor et al., 2015; Hubau et al., 2020; Phillips et al., 2009).

Losing tropical forests in the Amazon region through increased mortality under drought also has implications for regional

65 and continental scale water cycling (Ruiz-Vásquez et al., 2020). The rainforest transpires enormous amounts of water which is transported by winds to remote regions far beyond the borders of the rainforest (e.g. Dirmeyer et al., 2009; van der Ent et al., 2010; D. C. Zemp et al., 2014; Zemp et al., 2017a). In addition, the ongoing deforestation in the Amazon rainforest further decreases forest cover and thus, transpiration rates, leading to a rainfall decline and enhanced drought conditions in a positive feedback loop (Miralles et al., 2019; D. C. Zemp et al., 2017a; Zemp et al., 2017b). It can be expected that ongoing 70 climate change most likely will cause stronger and more frequent drought events in the Amazon (Cai et al., 2015; Jia et al., 2019; Marengo \& Espinoza, 2016).

For assessing the severity, the spatial extent and, in particular, the impacts of such drought events on existing ecosystems, different gridded precipitation datasets are available which in some cases differ strongly in magnitude and spatio-temporal distribution of precipitation amounts (Golian et al., 2019). Typical problems of precipitation data for South America encompass the underestimation of extreme rainfall events in both dry or wet seasons (Blacutt et al., 2015; Giles et al., 2020). 
https://doi.org/10.5194/bg-2020-425

Preprint. Discussion started: 2 December 2020

(c) Author(s) 2020. CC BY 4.0 License.

Therefore, while for the Amazon region, the recent drought events have been assessed in terms of severity (Jiménez-Muñoz et al., 2016; Jimenez et al., 2018) and impacts (Phillips et al. 2009, Lewis et al. 2011) based on single precipitation data sets, a systematic analysis of how the most frequent used precipitation datasets differ regarding the spatial extent, location and severity of recent extreme drought events, is currently missing.

80 For our study, we selected ten precipitation datasets: $(1,2)$ Data from the Tropical Rainfall Measurement Mission (TRMM) version 6 and 7 (Huffman et al., 2007) which have been frequently used, e.g. to estimate drought impacts on the carbon balance (Lewis et al., 2011; Malhi et al., 2009) and are assumed to represent precipitation patterns in the Amazon region best since they are derived from radar measurements (Huffman et al., 2007). (3) CHIRPS (Climate Hazards group Infrared Precipitation with Stations, Espinoza et al., 2019), which has been used to study regional hydro-climatic and environmental changes in the Amazon Basin. These two datasets only provide precipitation and no information about other climatic variables such as temperature or radiation. In addition, we selected five datasets that are often used as drivers for ecosystem models (e.g. in Forkel et al., 2019; Yang et al., 2015) and - in contrast to the other datasets - provide information about other climate variables: Data from the Climate Research Unit (CRU) with a joint project reanalysis (NCEP, National Centers for Environmental Prediction) applied, (4) the CRUNCEP (version 8, Viovy, 2018), (5) the WATCH-WFDEI (WATCH: Water and Global Change, Weedon et al., 2011. WFDEI: WATCH Forcing Data methodology applied to ERA-Interim, Weedon et al., 2014) dataset, originally derived from global sub-daily observations merged with integrations from a general circulation model, (6) the GSWP3 (Global Soil Wetness phase 3, Kim et al. in prep) dataset which is closely related to WATCHWFDEI, relying on a similar forcing but with a different bias correction applied, (7) the newer GLDAS s(Global Land Data Assimilation System) 2.1. which is derived from various geostationary infrared satellite measurements and microwave observations (Rodell et al., 2004), (8) the ERA-Interim dataset which is generated using a forecast model driven with different input datasets (Dee et al., 2011), (9) the latest ECMWF atmospheric reanalysis dataset, ERA5, which is the successor of ERA-Interim, providing higher spatial and temporal resolutions and a more recent model and data assimilation system than the previous ERA-Interim reanalysis (Albergel et al., 2018), and, finally, (10) the GPCC (named after the Global Precipitation Climatology Centre) dataset (Schneider et al., 2018), which is based on globally available land stations (rain gauges) combined with an empirical interpolation method (Willmott et al., 1985). A more detailed description of the datasets is given in the methods section.

We evaluate the precipitation datasets based on the Maximum Cumulative Water Deficit (MCWD; Aragão et al., 2007), a well-established drought index that is particularly suitable for estimating drought stress in the Amazon region (e.g. EsquivelMuelbert et al., 2019; Lewis et al., 2011; Y. Malhi et al., 2009; Phillips et al., 2009; Zang et al., 2020). In addition, we included two other measures to complement our analysis: Rainfall anomaly index (RAI), which does account for the mean deviation (in units of standard deviation) of precipitation during the driest months of the year and scPDSI (self-calibrating Palmer Drought Index, Wells et al., 2004). scPDSI has a more complex formulation compared to RAI and MCWD and takes available soil water content into account. Both RAI and scPDSI have been used in studies describing the recent Amazonian drought events (e.g. Jiménez-Muñoz et al., 2016; Lewis et al., 2011). 
https://doi.org/10.5194/bg-2020-425

Preprint. Discussion started: 2 December 2020

(C) Author(s) 2020. CC BY 4.0 License.

(c) (i)

110 The goals of our study are (1) to analyze and quantify the uncertainty in drought strength, extent and location of three recent Amazon droughts in the years 2005, 2010 and 2015/2016 in ten state-of-the-art precipitation datasets based on MCWD; (2) to examine differences among these drought events by taking two additional drought indicators RAI and scPDSI into account; and (3) give an estimate of the impacts of the three drought events on the carbon cycle by estimating potential biomass losses. 
https://doi.org/10.5194/bg-2020-425

Preprint. Discussion started: 2 December 2020

(c) Author(s) 2020. CC BY 4.0 License.

\section{(c) (i)}

\section{Methods}

\subsection{Study area}

Our study covers the Amazon river basin as delineated by Döll \& Lehner (2002, see black contour in Fig. 1). Using $0.5^{\circ}$ spatial resolution in longitude and latitude results in 1946 grid cells of interest for this study area. To compare spatial differences of drought extent in more detail, we subdivided the Amazon Basin into 13 regions based on countries and Brazilian states intersecting with the area (SI Fig. 1). Note that differences in the comparison of our results with Lewis et al. (2011) arise because of differences in the delineation of the Amazon region, i.e. the area used in our study is 0.6 Mio $\mathrm{km}^{2}$ larger.

\subsection{Data sources}

125 In the following, we briefly describe the ten precipitation datasets applied in our study (see also Table 1): The Tropical Rainfall Measuring Mission (TRMM v7) product (Huffman et al., 2007) is a precipitation-only dataset based on multiple microwave-infrared satellite data developed as a joint product between NASA and the Japan Aerospace Exploration Agency (JAXA). We also included the predecessor v6 for comparison in our study, because it has been frequently and prominently used to derive drought impacts to the Amazon Basin (e.g. Lewis et al., 2011; Phillips et al., 2009) and shows significantly

130 lower precipitation throughout the basin compared to v7 (Seto et al., 2011). Both TRMM datasets are from now on denoted as TR6 and TR7. CHIRPS (Climate Hazards group Infrared Precipitation with Station) is a novel dataset (Funk et al., 2015 from now on denoted CHR) which is a quasi-global (full longitude, but only $50^{\circ} \mathrm{S}-50^{\circ} \mathrm{N}$ latitude extent) precipitation-only merged product, based on multi-satellite estimates (similar to TR6 and TR7) and approx. 2,000 in-situ observations per month in South America. TR6, TR7 and CHR share the quasi-global spatial extent, however, in comparison to TR6 and TR7

135 with a resolution of $0.25^{\circ} \times 0.25^{\circ}$, CHR has a much higher spatial resolution of $0.05^{\circ} \times 0.05^{\circ}$. ERA-Interim (from now on denoted as ERI) is an atmospheric model that assimilates observation-based estimates from the GPCP-dataset (Adler et al., 2003) of the atmosphere during runtime (Dee et al., 2011). Although ERI might show some anomalies in tropical biomes (Di Giuseppe et al., 2013), it has been used for drought evaluation of the Amazon rainforest (Jiménez-Muñoz et al., 2016) and also as a forcing dataset for dynamic vegetation models (DVMs; e.g. Maignan et al., 2011; Poulter et al., 2011). ERA5

140 (Muñoz-Sabater et al., 2018), from now on denoted as ER5, shows improvements in, e.g., land evapotranspiration, surface soil moisture and turbulent heat fluxes over its predecessor ERI (Albergel et al., 2018). Similarly, CRUNCEP (Viovy, 2018 from now on denoted as CRU) is generated based on a reanalysis from the national centers for environmental prediction (NCEP) and the National Center for Atmospheric Research (NCAR), corrected with the CRU TS3.2 (Harris et al., 2014) dataset. GPCC (from now on denoted as GPC) is mainly based on data from rain gauge land stations. Similar to CRU, it is

145 also based on a reanalysis and has been used in global drought studies (Ziese et al., 2014). Both GPC and CRU cover the longest periods of all selected datasets in this study with timespans from 1891 until 2016 and from 1901 until 2016, respectively. WATCH-WFDEI (denoted as WAT from now on; Weedon et al., 2011; 2014) is based on the reanalysis ERI 
https://doi.org/10.5194/bg-2020-425

Preprint. Discussion started: 2 December 2020

(c) Author(s) 2020. CC BY 4.0 License.

\section{(c) (i)}

corrected with GPC precipitation. GSWP3 (Kim et al. in prep; from now on denoted as GSW) is based on the atmospheric reanalysis method "20CR" (20th Century Reanalysis version 2, Compo et al., 2013), which has been dynamically downscaled to $0.5^{\circ} \times 0.5^{\circ}$ resolution. Corrections with observational data have not only been applied to precipitation but also to short/longwave radiation, air temperature and the daily temperature range. Both WAT and GSW end in the year 2010. The GLDAS 2.1 (from now on denoted as GLD) dataset is built by using the 'Noah Land surface model' forced by the Goddard Earth Observing System (GEOS) Data Assimilation System with corrected precipitation and radiation (Rodell et al., 2004; Sheffield et al., 2006). Starting in January 2000 (Version 2.1), it is the dataset with the latest time onset and hence defines the lower-bound time interval considered in this study. For the 2015/2016 drought event, only seven datasets were available as three of the datasets (TR6, GSW and WAT) end before. All datasets were (if not directly available) converted to $0.5^{\circ} \mathrm{x}$ $0.5^{\circ}$ spatial resolution and to monthly time steps.

\subsection{Drought indices and evaluation of drought area and extent}

\subsubsection{Calculation of maximum climatological water deficit (MCWD)}

160 We calculate MCWD based on Aragão et al. (2007) defining water deficit (WD) as follows:

$W D(t)=P(t)-E T(t)$,

where $W D(t)$ stands for water deficit, which is calculated for a time step t, in this case for a monthly time step, $P(t)$ for monthly precipitation and $E T(t)$ for monthly evapotranspiration. To estimate the impacts of persistent drought events, the cumulative water deficit (CWD) is defined as the accumulation of water deficit of each month of the hydrological year (see below for details) for which $P(t)$ is smaller than $E T(t)$, hence $W D(t)$ is negative. MCWD is the most negative value of $C W D(\mathrm{t})$ over a specific period. For a complete mathematical definition, see Supporting Information Methods S1. As proposed by Aragão et al. (2007), we use a fixed value for $E T(t)=E T_{\text {fixed }}=100 \mathrm{~mm}$ month $^{-1}$ derived from ground measurements of evapotranspiration in different locations and seasons in Amazonia (von Randow et al., 2004; da Rocha et al., 2004). As a result, water deficit builds up whenever the monthly rainfall $P(t)$ falls below $100 \mathrm{~mm}$.

170 We calculate annual MCWD for the hydrological year from October of the previous year to September of the succeeding year, e.g. the MCWD for the year 2000 is calculated from October 1999 to September 2000 (similar to Lewis et al., 2011). Similarly, for deriving the drought severity, we calculated the MCWD anomaly ( $\triangle \mathrm{MCWD)}$ ) for 2005 and 2010 by first calculating the mean MCWD for the "baseline" period from 2000 to 2010, thereby excluding the years 2005 and 2010. To derive $\triangle \mathrm{MCWD}$, the baseline period is subtracted from the mean value of 2005 and 2010, respectively. The same procedure

175 was applied for calculating $\triangle \mathrm{MCWD}$ for 2016, extending the baseline period to from 2000 to 2016 and additionally excluding the year 2016. We excluded the drought years from the baseline period as the high proportion of drought years would bias the mean water stress (Lewis et al., 2011). We investigated also the effect of including drought years in the baseline calculation and the role of a longer baseline period (Fig. S1). Similar to Lewis et al. 2011, we defined $\triangle \mathrm{MCWD}<$ 
https://doi.org/10.5194/bg-2020-425

Preprint. Discussion started: 2 December 2020

(c) Author(s) 2020. CC BY 4.0 License.

(c) (i)

$-25 \mathrm{~mm}$ as moderate drought stress because at this level, tree mortality already significantly increased in their inventory plots. We further defined $\triangle \mathrm{MCWD}<-100 \mathrm{~mm}$ as severe and $\triangle \mathrm{MCWD}<-150 \mathrm{~mm}$ as extreme drought stress.

\subsubsection{Calculation of rainfall anomaly index (RAI)}

For the rainfall anomaly index, dry season rainfall was taken as the mean precipitation from July-September following Lewis et al. (2011). For each year, the 'standardized anomaly' was calculated as the anomaly of rainfall expressed as the difference in units of standard deviation from the mean dry season rainfall over all years. Like for to the MCWD calculation, we excluded the drought years 2005 and 2010 from the mean dry season precipitation calculation from a baseline period 20002010 to investigate the drought impacts of 2005 and 2010, and for 2016 we selected a baseline period from 20002016 excluding 2005, 2010 and 2016. We defined $R A I<-1$ to represent moderate, $R A I<-2$ to represent severe, and RAI < -3 to represent extreme drought stress.

\subsubsection{Calculation of the self-calibrating Palmer Drought Severity Index (scPDSI)}

The self-calibrating Palmer Drought Severity Index (scPDSI, Wells et al., 2004) has in recent studies been used to assess the impacts of droughts on the Amazon basin (e.g. Jiménez-Muñoz et al., 2016). It improves the original PDSI by using a selfcalibrating procedure based on historical climate data, eliminating the empirically derived climatic characteristics. Next to precipitation, it also takes monthly potential evapotranspiration ET into account. In our study, we use ET data generated by the ER5 reanalysis. Additionally, the scPDSI takes soil water capacity as input, which we assumed here as a constant value of $100 \mathrm{~mm}$. scPDSI was estimated using the $R$ package $s c P D S I$ (Ruida et al., 2018).

To enable comparison with the MCWD and RAI, we selected identical baseline periods from 2000 to 2010 for the 2005 and 2010 events and from 2000 to 2016 for the 2016 drought event. We also adopted the categorization from Jiménez-Muñoz et

200 al. (2016) and Wells et al. (2004) with scPDSI $<-2$ representing moderate, scPDSI $<-3$ severe and $s c P D S I<-4$ extreme drought stress.

\subsection{Calculation of drought area and extent}

Each grid cell's area was approximated as a trapezoid to its boundary coordinates (in $0.5^{\circ} \times 0.5^{\circ}$ resolution), resulting in an area between 2900 and $3090 \mathrm{~km}^{2}$ per grid cell. Accumulating the associated areas over all grid cells resulted in a total area of 2055.94 million $\mathrm{km}^{2}$ representing the Amazon Basin. Note that for comparison of our results with Lewis et al. (2011) differences in absolute areas arise because of differences in study area size (5.94 vs. 5.3 million $\mathrm{km}^{2}$, respectively). For the calculation of the drought-affected area, we summed up the area of grid cells that matched the respective drought classification (e.g. $\triangle \mathrm{MCWD}<-150 \mathrm{~mm}$ for extreme drought stress). The spatial agreement of drought location among datasets was estimated by selecting the grid cells matching the drought classification per dataset and subsequently counting the number of datasets per grid cells showing the respective drought classification. 
https://doi.org/10.5194/bg-2020-425

Preprint. Discussion started: 2 December 2020

(c) Author(s) 2020. CC BY 4.0 License.

(c) (1)

\subsection{Estimating carbon losses during drought events}

To estimate carbon loss during drought events, we used a simple linear relation between MCWD and carbon losses in the 215 Amazon basin derived from plot measurements (Lewis et al., 2011):

$\Delta \mathrm{AGB}=0.3778-0.052 * \Delta \mathrm{MCWD}$

Here, $\triangle \mathrm{AGB}$ denotes the change in aboveground biomass, i.e. biomass carbon losses. The equation was derived from

220 Amazon plot inventory data measured across the RAINFOR network to estimate the impact of the 2005 drought event (Lewis et al. 2011). To calculate $\triangle \mathrm{AGB}$ in Eq. 2, we used the $\triangle \mathrm{MCWD}$ of each gridcell for each drought year calculated for each of the precipitation datasets in our study. The total biomass carbon loss (in Pg C) across the Amazon basin is then calculated by summing up $\triangle \mathrm{AGB}$ for all gridcells weighted by each gridcell's size. 
https://doi.org/10.5194/bg-2020-425

Preprint. Discussion started: 2 December 2020

(c) Author(s) 2020. CC BY 4.0 License.

(c) (i)

\section{Results}

All areas in the following section are expressed as percentage with respect to the entire Amazon basin according to our delineation (5.94 million $\mathrm{km}^{2}$ ). For an overview of the areas affected in million $\mathrm{km}^{2}$, see Table 2 and 3.

\subsection{Comparison of total drought area based on $\triangle \mathrm{MCDW}$}

230 We first evaluate differences in the two TRMM products, TR6 and TR7. For 2005 and 2010, we find similar spatial patterns for TR7, as in Lewis et al. 2011 for TR6 (Fig. 1a, b). Regarding drought intensities, TR7 agrees with its predecessor TR6 for 2005 , showing a slightly smaller area (4\% less), but an 11\% smaller area for $2010 . \Delta$ MCWD calculated from TR7 indicates that the North-Western region of the Amazon Basin (particularly the Roraima region) was hit extremely by drought stress in 2016 with $7 \%$ of the area having $\triangle \mathrm{MCWD}<-150 \mathrm{~mm}$ (Fig. 1c). Furthermore, in 2016 about $15 \%$ of the basin was severely

235 affected by drought stress located at the Western part and scattered in South-Eastern Amazonia. Moderate drought stress was found throughout $54 \%$ of the basin also affecting central and western Amazonia (Fig 1c).

Across all precipitation datasets, in 2005, an area ranging from 46 to $71 \%$ (mean 53\%) of the whole Amazon basin was moderately affected (Table 2, Fig. 2a). GSW and GLD displayed the smallest area affected by moderate drought (2.6 million $\mathrm{km}^{2}$, Tab. 1, Fig. 2), while ER5 showed a vast affected area (4.2 million $\left.\mathrm{km}^{2}\right)$, an area about $12 \%$ larger than displayed by ERI. For severe and extreme drought conditions, CHR shows the smallest affected area with $6 \%$ of the basin and no affected area, respectively. For severe drought conditions, CRU suggests that approximately $16 \%$ more of the basin area was affected in comparison to CHR (1.6 million $\mathrm{km}^{2}$ vs. 0.4 million $\mathrm{km}^{2}$ ). CRU also encompasses the largest area of extreme drought stress $\left(0.7\right.$ million $\mathrm{km}^{2} ; 12 \%$ of the basin less than $\left.\triangle \mathrm{MCWD}<-150 \mathrm{~mm}\right)$.

245 During the 2010 drought, a larger area was affected by moderate drought ranging between a minimum of 52\% (GPC) and a maximum of $76 \%$ (TR6), which is about 10\% larger than during the 2005 drought (3.1 million $\mathrm{km}^{2}$ vs. 4.6 million $\mathrm{km}^{2}$, Tab. 2, Fig. 2). In addition, the area with severe drought extent was on average $3 \%$ larger compared to 2005 . The area affected by extreme drought was smaller than during the 2005 drought. Particularly, ER5 and TR6 showed the largest area affected throughout the three drought classifications (Fig. 2b).

For 2016, two datasets (CHR and CRU) showed with $40 \%$ a considerably smaller area that was moderately affected by drought compared to ER5 and ERI with 69\% and 63\% of the area affected, respectively (datasets ranging between 2.4 and 4.1 million $\mathrm{km}^{2}$ ). Generally, in 2016, the size of the area affected by moderate drought was in between the size of the area affected 2005 and 2010, but the extent of severely and extremely drought-affected areas was larger. Here, particularly ERI (closely followed by ER5) showed the largest affected area, with 30\% severely affected and 18\% extremely affected. 
https://doi.org/10.5194/bg-2020-425

Preprint. Discussion started: 2 December 2020

(c) Author(s) 2020. CC BY 4.0 License.

\section{(c) (i)}

\subsection{Spatial agreement of rainfall datasets using $\triangle \mathrm{MCDW}$}

While the agreement of total area affected by drought is relatively high (see 3.1), the data sets are only partly in agreement regarding the spatial patterns and locations of the 2005, 2010 and 2016 droughts (Fig. 3). For 2005, all datasets are in agreement regarding the drought epicenter being located in Central Amazonia mainly affecting the Brazilian states Amazonas and Acre (Fig. S4 b, d). All ten datasets also agree that an area of about $15 \%$ of the Amazon Basin was at least moderately affected (Fig. 3a). Only a small overlap was found for the area affected by severe and extreme drought stress (Fig. 3b, c). Here, only half of the datasets agreed on $11 \%$ of central Amazonia being severely and $4 \%$ extremely affected.

For 2010, all datasets agreed on an affected area of $11 \%$ in the Amazon basin, and half of the datasets agreed on an area of $72 \%$ of the Amazon Basin being moderately affected by drought stress (Fig. 3d). The 2010 drought displayed no central hotspot, but three most affected areas in the Eastern, Southern and central part of Amazonia on which most of the datasets agreed (Fig. 3d). Severe drought stress in 2010 was located in the southern part of Amazonia, where four datasets agreed (Fig. 3e), while for extreme drought stress almost no overlap between datasets was found (Fig. 3f).

For 2016, all datasets agreed on an area of about $8 \%$ for moderate drought stress and half of the datasets agreed on $54 \%$ of the basin being affected (Fig. 3g). Agreement for severe and extreme drought stress was higher compared to the other drought years (Fig. 3h, i). Most of the data sets located the epicenter of the drought in the North-Western part of Amazonia. Some datasets also showed the South-Central part of the basin being severely affected (Fig 3i).

\subsection{Estimating the variation of carbon losses during drought events}

For the different precipitation datasets and based on the linear relation between $\triangle \mathrm{MCWD}$ and $\triangle \mathrm{AGB}$, we derive carbon losses for 2005 to be in the range of 1.3-1.9 Pg C with CHR showing the smallest and CRU the strongest impact regarding carbon losses (Fig. 4). The mean biomass loss over all datasets was 1.6 Pg C with six of the ten estimates from the different datasets being close to that mean (difference of $\triangle \mathrm{AGB}$ less than $0.15 \mathrm{PgC}$ to the mean value). For 2010, carbon losses range from 1.5 to $2.3 \mathrm{Pg} \mathrm{C}$ with WAT showing the smallest and TR6 strongest response. Next TR6 also ER5 shows a very strong drought impact with 2.3 PgC. All other datasets show much smaller impacts between 1.6 and $1.8 \mathrm{Pg}$ C comparable to the 2005 drought impact. The 2016 drought event shows the widest range of biomass loss across datasets ranging from $1.3 \mathrm{PgC}$ 280 to $2.5 \mathrm{PgC}$. The disagreement between datasets is also larger for 2016 compared to 2005 and 2010: Both, CRU and CHR show a low impact of 1.3 Pg C, TR7 and GPC show 1.7 Pg C biomass loss comparable to the averages of 2005 and 2010. GLD, ER5, and ERI show very strong impacts of 2.1, 2.3 and 2.6 Pg C, respectively.

\subsection{Comparison of drought indices: $\triangle \mathrm{MCDW}$, scPDSI and RAI}

Similar to $\triangle \mathrm{MCWD}$, there is variable agreement among datasets when evaluating the other two drought metrics, RAI and 285 scPDSI (Fig. 5). scPDSI showed the lowest agreement across datasets, with mainly two datasets in agreement on areas 
https://doi.org/10.5194/bg-2020-425

Preprint. Discussion started: 2 December 2020

(c) Author(s) 2020. CC BY 4.0 License.

\section{(c) (i)}

affected by drought for 2005. Regarding the total area affected in 2005, TR7 showed the largest area (48\% of the Amazon basin, 2.8 million $\mathrm{km}^{2}$ ) and GLD (32\%, 1.9 million $\mathrm{km}^{2}$, Table 2) the smallest area affected by drought stress. Severe drought-stressed areas ranged between 16\% (GLD) and 26\% (CRU) and extreme drought stress between 1\% (GLD) and 5\% (CRU) of the basin affected. The largest rainfall anomaly (RAI) for moderate drought stress in 2005 was displayed by CHR with 52\% (3.1 million $\mathrm{km}^{2}$, Table 2), followed by ER5 with $49 \%$ of the area affected. CRU showed with $29 \%$ the smallest area affected by drought stress. The area of severe drought stress was smaller using RAI compared to scPDSI, ranging from 9 to $20 \%$. In general, the datasets displayed a more spatially connected area in the center of the Amazon basin when using RAI compared to scPDSI. RAI and MCWD agreed on the spatial location of the drought, while scPDSI showed severe drought stress in a different region (Fig 5a, d, g): Some areas showed a strong disagreement between drought indices, e.g. a small area in Western Brazil and Peru was hit by severe drought stress according to $\triangle \mathrm{MCWD}$ and RAI (with all climate datasets in agreement). In contrast, scPDSI did not indicate abnormally dry conditions there.

In 2010, the total droughted area was similar for scPDSI and smaller for RAI compared to MCWD regarding severe drought stress (Fig. 5b, e, h): For scPDSI, in particular, GLD showed a large area of 50\% of the basin severely affected (2.9 million $\mathrm{km}^{2}$, Table 2), followed by CRU showing 33\% affected using scPDSI. The agreement between datasets was lower compared to the 2005 drought for both RAI and scPDSI. $\triangle$ MCWD and scPDSI showed similar areas in the southern Amazon Basin severely affected by drought. According to RAI, datasets agreed on the severely affected area in the North-Western part of Amazonia, diverting from the other indices (Fig 5h).

For 2016, scPDSI showed the largest area affected by drought stress with GLD showing $62 \%$ (followed by TR7, 52\%) of the basin being severely affected. Four datasets agreed on the affected area in the northeastern part of the basin (Fig. 5f). Hardly any drought stress was visible in 2016 when calculating rainfall anomalies (RAI, Fig 5i), indicating no pronounced anomalies in dry season rainfall. Only GLD diverted from the other datasets showing 30\% of the area under severe drought stress, while all other datasets found between $0-1 \%$ of the area to be affected (Table 3). $\triangle \mathrm{MCWD}$ and scPDSI again agreed on the spatial extent of the droughted area (Fig. 5c, f). Generally, scPDSI showed a much larger area severely affected by drought stress over $\triangle \mathrm{MCWD}$ and RAI.

310 Seasonal patterns of median $\triangle \mathrm{MCWD}$ across the Amazon basin were consistent for 2005, where all datasets showed a sudden drought impact (decline in $\triangle \mathrm{MCWD}$ ) from July onwards. Only ERI and ER5 displayed a small decline already in the months before July. The 2010 drought followed similar patterns regarding $\triangle \mathrm{MCWD}$, with a lower absolute impact (Fig 6b). For 2015, datasets agreed on a small decline in $\triangle$ MCWD followed by a more substantial impact in 2016 with fewer datasets in agreement (Fig 6c). Datasets agreed well according to the seasonal patterns of scPDSI for 2005 and 2010 (Fig 6d, e). This

315 agreement was lower for the year 2016, in which CRU, GLD and TR7 indicate drought stress already starting in January, and ERI and ER5 only starting in September (Fig. 6f). All datasets showed a period of drought stress for longer than 12 months. Datasets generally agreed on rainfall anomaly (RAI) patterns for all of the drought years 2005, 2010, and 2016 (Fig. 
https://doi.org/10.5194/bg-2020-425

Preprint. Discussion started: 2 December 2020

(C) Author(s) 2020. CC BY 4.0 License.

(c) (i)

6g, h, i). For 2005 the difference in rainfall was highest in June-July and for 2010 in March, August and September. The 2015/2016 drought event showed a long period of strong (negative) rainfall anomaly from August 2015 to July 2016 (Fig. 320 6i). 
https://doi.org/10.5194/bg-2020-425

Preprint. Discussion started: 2 December 2020

(c) Author(s) 2020. CC BY 4.0 License.

(c) (i)

\section{Discussion}

We assessed the severity and spatial extent of the extreme drought years 2005, 2010, and 2015/2016 in the Amazon region and their impacts on the carbon cycle. When analyzing drought representation in ten different precipitation datasets for the Amazon basin, we find that while the datasets mostly agree on the extent of the drought area, they differ in their location of drought. We show that biomass losses during 2005 and 2010 were about $1.8 \mathrm{PgC}$, indicating that the more intense drought in 2005 equals a larger total area of the 2010 drought regarding biomass loss. In 2015/2016, we find a large variability of biomass losses depending on the precipitation dataset used, ranging from 1.3 to $2.7 \mathrm{PgC}$.

330 Critical aspects regarding the detection of drought events in the Amazon basin

\section{Drought indices}

MCWD is one of the most widely used measures to assess drought stress in tropical forests (e.g. Lewis et al., 2011, Phillips et al., 2009, Esquivel-Muelbert et al., 2019). The calculation of MCWD only requires precipitation data and assumes a constant evapotranspiration (ET) rate of $100 \mathrm{~mm} \mathrm{month}^{-1}$ (Aragão et al., 2007). Although the simplicity of $\triangle \mathrm{MCWD}$ is a main advantage, a fixed ET (which we also used in our study) is inappropriate for regions other than the lowland tropics, where the lower supply of energy may result in lower ET values. Most importantly, an approximated ET does not account for either seasonal variation (driven mainly by radiation, temperature and phenology) or spatial variation in ET related to soil and root properties (Malhi et al., 2009). Hence, changes in $\triangle$ MCWD are purely accounting for changes in rainfall (Phillips et al., 2009). In contrast, scPDSI is driven with spatially and temporally resolved evapotranspiration data (here: ER5).

340 However, currently available evapotranspiration products for the Amazon rainforest show significant differences in areas and extent of evapotranspiration (Sörensson and Ruscica, 2018), hence introducing another source of uncertainty when using it for the calculation of drought indices.

The key difference between the three drought indices applied in our study is the temporal resolution: RAI is only calculated for the three driest months (July-September) and thus, for example, a rainy season with deficient rainfall is not captured.

$345 \triangle \mathrm{MCWD}$, in contrast, accumulates over 12 months and is reset to zero at the end of the hydrological year. In this way, drought events caused by low precipitation in both dry- and rainy season are captured, however, drought events lasting for longer than a year are not detected. scPDSI is not reset to zero at the end of the hydrological year and is thus captures also multi-year drought events. As an example, the 2015/2016 drought event is classified as a severe multi-year drought according to Yang et al. (2018), which is also displayed in our analysis when using scPDSI (all datasets in agreement that more than $30 \%$ of the area were affected, Tab. 3). $\triangle \mathrm{MCWD}$ and RAI, however, do not agree on a spatially and temporally extensive drought event (Fig. 5c, f, g, Tab. 3), but instead display distinct regions of severe drought stress. Thus, this drought event seemed not to be characterized by particularly low dry-season precipitation, but by low precipitation accumulated over a longer time period. scPDSI and $\triangle \mathrm{MCWD}$ roughly agreed on spatial extent but scPDSI showed a more substantial drought impact indicating that precipitation levels might have been already lower than usual during the years before the 2016 drought 
https://doi.org/10.5194/bg-2020-425

Preprint. Discussion started: 2 December 2020

(c) Author(s) 2020. CC BY 4.0 License.

\section{(c) (i)}

event happened, indicating a multi-year drought event (Yang et al., 2018). Seasonal patterns of the three drought indices support this assumption (Fig. 6): Resetting MCWD once per year neglects any influences of drought events of the preceding year (Fig. 6c).

A common drawback of all drought metrics used in our study is their incapability to explicitly represent the effect of increasing atmospheric vapor pressure deficit (VPD) on plant water stress. A steady amplification of atmospheric vapor pressure deficit (VPD) has been detected over the Amazon basin (Barkhordarian et al., 2019; Rifai et al., 2019). Such stronger atmospheric water demand leads to additional water loss of plants during drought, subsequently increasing the severity of droughts. Hence, the role of VPD during drought and as a driver for plant stress should not be underestimated (Grossiord et al., 2020). With increasing data availability and better estimates of VPD across the Amazon region, it should be included in future drought assessments (e.g. Castro et al., 2020). Furthermore, in the last decade, new methods have been developed that assess impacts of drought on ecosystems, e.g. analyses based on solar-induced fluorescence (SIF) data show that tall forests are less sensitive to rainfall compared to short forests (Giardina et al., 2018). Also, vegetation optical depth (VOD) used as a proxy for water content in forests is a promising satellite-derived indicator for mortality and impacts of droughts to forests (Rao et al., 2019). However, conducting analyses over the Amazon rainforest based on VOD is difficult, because VOD data across tropical regions is often noisy as the high cloud cover over the rainforests generates erroneous signals (Konings and Gentine, 2017). Future studies should estimate the impacts of droughts based on multiple drought characteristics, e.g. Toomey et al. (2011) show that considering both, heat stress and soil moisture stress greatly improves the explanatory power of drought impacts in the Amazon basin.

\section{Precipitation datasets}

375 For the three drought events in 2005, 2010 and 2016, ERI and ER5 diverted the most from the other datasets regarding the size of the area affected by drought. Especially ER5 shows the largest area of moderate drought stress during all three drought events (Fig. 2). Although TR7 and CHR are based on the same satellite data as the input, they differ regarding the size of the drought area, especially during 2016 (Fig. 2). Lewis et al. (2011) estimated an area of $47 \%$ (2.5 million $\left.\mathrm{km}^{2}\right)$ of the Amazon basin moderately affected in 2005 using the TR6 dataset, which compares well with the size of the affected area in the GLD, GPC, and GSW datasets analysed in our study (considering our 0.6 million $\mathrm{km}^{2}$ larger study area; see Methods). For 2010, Lewis et al. (2011) reported an area of 3.2 million $\mathrm{km}^{2}$ being affected in comparison to 4.5 million $\mathrm{km}^{2}$ in our analysis using TR6 with very similar spatial patterns. The newer TRMM product, TR7, however, shows less frequent rainfall but heavier rainfall than CHR maintaining a similar total amount (Giles et al., 2020). Also, both TRMM versions (TR6 and TR7) differ regarding the total area affected by drought in 2005 and in particular in 2010 with TR6 showing a $14 \%$ larger

385 area of the Amazon basin affected in our analysis. This can be explained by the generally higher precipitation rates detected in the TR7 dataset in comparison to TR6 (Seto et al., 2011) leading to lower absolute values of $\triangle \mathrm{MCWD}$. Spatially, this difference was most pronounced in the western and northern parts of Amazonia, in the Acre and Roraima states, and in Peru. Because of such higher precipitation rates in TR7 as compared to TR6, and subsequently the much stronger drought response 
https://doi.org/10.5194/bg-2020-425

Preprint. Discussion started: 2 December 2020

(c) Author(s) 2020. CC BY 4.0 License.

according to our analysis, studies only based on TR6 might overstate the actual drought conditions and should be revisited.

Precipitation datasets usually show remarkable differences in the representation of occurrence, frequency, intensity and location of events, mainly due to their nature of high spatial and temporal variability (Covey et al., 2016; Dirmeyer et al., 2012). Generally, the sparse network of observations in the Amazon rainforest may explain the differences across precipitation datasets and drought indices for datasets that rely on station data. Within the last decade, the number of observations increased, due to a new denser network of stations. This may improve the reanalysis models that are used for several precipitation datasets applied here, however, it does not improve datasets that only rely on gauge observations.

According to Jiménez-Muñoz et al. (2016), 40\%, 25\% and 10\% of the Amazon basin were affected by moderate, severe and extreme drought stress in March 2016 when using scPDSI, respectively. This is similar to our estimate (46\%, 34\% and 9\%, moderately, severely and extremely affected in Sep 2016) based on the same precipitation dataset (ERI). Our estimate slightly diverted from the results of Jiménez-Muñoz et al. (2016), again at least partly due to a different reference area (see Methods). In addition, they used spatially resolved information on soil water capacity when calculating scPDSI and a longer baseline period (start year is 1979 in their study vs. 2000 in our study). scPDSI generally seems to be more sensitive to baseline changes (Fig S2e). In addition, also the choice of the precipitation dataset plays an important role. In regions, in which ER5 showed an extremely affected area of only 5\%, other datasets such as GLD and TR7 showed a much stronger drought impact with over $70 \%$ of the area moderately and between $50 \%$ and $60 \%$ severely affected. This is particularly interesting because recent studies identify TR7, CHR and ER5 as best precipitation datasets when comparing to gauge observations in South America (Albergel et al., 2018; Burton et al., 2018; Rifai et al., 2019). The higher variability that scPDSI showed across datasets can be explained with the more complex algorithm (including the self-calibrating mechanism) compared to MCWD and RAI.

\section{Implications for estimating drought impacts on the carbon cycle of the Amazon rainforest}

Drought leads to increased tree mortality and carbon losses in tropical forests (Hubau et al., 2020; Lewis et al., 2011; Phillips et al., 2009). With the prospect of more severe and frequent droughts in a future climate, more precise estimates of how much carbon is lost from reductions in growth and drought-induced mortality are necessary. Currently, the Amazon rainforest is acting as a carbon sink, thereby removing $\mathrm{CO}_{2}$ from the atmosphere, but with more frequent and severe drought

415 events, this sink is already declining (Hubau et al. 2020). Lewis et al. (2011) estimated a total loss of biomass for the Amazon basin in 2005 of $1.6 \mathrm{Pg} \mathrm{C}$ and a 38\% more severe impact of $2.2 \mathrm{Pg} \mathrm{C}$ for 2010 based on TR6. When applied to the $\triangle \mathrm{MCWD}$ derived from the precipitation datasets in our study, we calculate the loss of biomass of the 2005 drought event to be in the range of 1.3-1.8 Pg C, 1.5-2.3 Pg C in 2010 and 1.3-2.5 Pg C in 2016 (Fig. 4). This corresponds to approximately the average annual carbon uptake (1-2 PgC) per year, thus, turning the carbon sink into a carbon source. We acknowledge that our estimates are based on a relatively simple, empirically derived relation that does not take the biomass variability across the whole Amazon basin and individual forest/tree responses to drought into account. It however gives a rough estimate of potential carbon losses during drought and an idea of how much it varies depending on the precipitation datasets 
https://doi.org/10.5194/bg-2020-425

Preprint. Discussion started: 2 December 2020

(c) Author(s) 2020. CC BY 4.0 License.

(c) (i)

applied in a study. In addition, we would like to note that the empirical biomass-MCWD relation from Lewis et al. (2011) has been estimated with constant ET=100 mm. When using evapotranspiration data (from ER5) for the calculation of MCWD, we find higher biomass losses (Fig. S2), and thus, the use of MCWD should be carefully viewed via its sensitivity to ET. In our analysis, MCWD appears to be robust against changes to some parameters, such as baseline period and inclusion/exclusion of drought years, but to be more sensitive to the evapotranspiration input.

Furthermore, our estimated carbon losses for the drought events might be underestimated as (1) the total duration of the drought was longer than 12 months (see above paragraph and Fig. 6) and can hence not be fully captured by the standard 12month period of the MCWD calculation used in this study, and (2) potential lag effects through delayed plant mortality within the subsequent years are not considered so far. We would recommend for future studies to investigate the relationship of biomass losses with other drought indices (such as scPDSI) in a similar manner as done in Lewis et al. (2011). As the biomass of the Amazon rainforest is heterogeneously distributed (e.g. Saatchi et al., 2011), large-scale biomass-loss induced by drought (i.e. severe $\triangle \mathrm{MCWD}$ ) should be interpreted carefully. Differences in the amount of biomass in different forest types, species composition and critical hydraulic processes should be considered when estimating potential biomass losses under drought stress. A step forward would be to use for example remotely sensed biomass maps to account for regional biomass distributions (e.g. Avitabile et al., 2016) or to simulate drought impacts with dynamic global vegetation models (DGVMs). DGVMs simulate the carbon- and water cycle of the biosphere in a process-based way, accounting for the interplay of carbon uptake and water loss through stomatal opening, evapotranspiration (ET), carbon assimilation via photosynthesis, and carbon allocation to different plant compartments such as leaves, wood, and roots (e.g. Schaphoff et al., 2018; Smith et al., 2014). The simulated response of tropical forests in DGVMs is particularly sensitive to precipitation input under present and future climate change scenarios (e.g. Seiler et al., 2015) and thus, it might be relevant to use multiple climate forcing datasets to test for climate data uncertainty. Particularly, studies based on ERI and TR6 should possibly be revisited and include another forcing dataset for their analysis.

\section{Conclusions}

We find substantial variation in the spatial extent, location and timing of the extreme drought events in the years 2005, 2010 and 2016 in the Amazon basin. The variation partly results from the application of different drought metrics (MCWD, RAI, scPDSI) and from differences in the underlying precipitation datasets. Such differences also propagate when quantifying the impacts of drought on the carbon cycle of the Amazon rainforest and result in a large variability in biomass carbon losses, as we show in our analyses. This calls for the application of an ensemble of climate (precipitation) datasets and drought metrics when assessing the impacts of drought. Communicating the uncertainty in the estimation of drought events and their impacts on the Amazon rainforest is highly relevant and thus, multiple datasets should be applied by any large-scale study on drought impacts on vegetation. 
https://doi.org/10.5194/bg-2020-425

Preprint. Discussion started: 2 December 2020

(C) Author(s) 2020. CC BY 4.0 License.

(c) (i)

\section{Code availability}

All scripts to reproduce analysis and figures are available at https://github.com/PhillipPapastefanou/DroughtAnalysis

\section{Data availability}

460 All datasets are available following the references in the method section.

\section{Author contribution}

P.P. and A.R. conceived the study and wrote the first draft of the manuscript. All authors contributed to the development of the analysis and the writing of the manuscript.

465

\section{Competing interests}

The authors declare no competing interests. 
https://doi.org/10.5194/bg-2020-425

Preprint. Discussion started: 2 December 2020

(c) Author(s) 2020. CC BY 4.0 License.

(c) (i)

\section{References}

Adler, R. F., Huffman, G. J., Chang, A., Ferraro, R., Xie, P.-P., Janowiak, J., Rudolf, B., Schneider, U., Curtis, S., Bolvin, D., Gruber, A., Susskind, J., Arkin, P. and Nelkin, E.: The Version-2 Global Precipitation Climatology Project (GPCP) Monthly Precipitation Analysis (1979-Present), J. Hydrometeorol., 4(6), 1147-1167, doi:10.1175/15257541(2003)004<1147:TVGPCP>2.0.CO;2, 2003.

Albergel, C., Dutra, E., Munier, S., Calvet, J.-C., Munoz-Sabater, J., de Rosnay, P. and Balsamo, G.: ERA-5 and ERAInterim driven ISBA land surface model simulations: which one performs better?, Hydrol. Earth Syst. Sci., 22(6), 35153532, doi:10.5194/hess-22-3515-2018, 2018.

Aragão, L. E. O. C., Malhi, Y., Roman-Cuesta, R. M., Saatchi, S., Anderson, L. O. and Shimabukuro, Y. E.: Spatial patterns and fire response of recent Amazonian droughts, Geophys. Res. Lett., 34(7), doi:10.1029/2006GL028946, 2007.

Avitabile, V., Herold, M., Heuvelink, G. B. M., Lewis, S. L., Phillips, O. L., Asner, G. P., Armston, J., Ashton, P. S., Banin, L., Bayol, N., Berry, N. J., Boeckx, P., de Jong, B. H. J., DeVries, B., Girardin, C. A. J., Kearsley, E., Lindsell, J. A., LopezGonzalez, G., Lucas, R., Malhi, Y., Morel, A., Mitchard, E. T. A., Nagy, L., Qie, L., Quinones, M. J., Ryan, C. M., Ferry, S. J. W., Sunderland, T., Laurin, G. V., Gatti, R. C., Valentini, R., Verbeeck, H., Wijaya, A. and Willcock, S.: An integrated pan-tropical biomass map using multiple reference datasets, Glob. Chang. Biol., 22(4), 1406-1420, doi:10.1111/gcb.13139, 2016.

Barkhordarian, A., Saatchi, S. S., Behrangi, A., Loikith, P. C. and Mechoso, C. R.: A Recent Systematic Increase in Vapor Pressure Deficit over Tropical South America, Sci. Rep., 9(1), 15331, doi:10.1038/s41598-019-51857-8, 2019.

Blacutt, L. A., Herdies, D. L., de Gonçalves, L. G. G., Vila, D. A. and Andrade, M.: Precipitation comparison for the CFSR, MERRA, TRMM3B42 and Combined Scheme datasets in Bolivia, Atmos. Res., 163, 117-131, doi:10.1016/j.atmosres.2015.02.002, 2015.

Burton, C., Rifai, S. and Malhi, Y.: Inter-comparison and assessment of gridded climate products over tropical forests during the 2015/2016 El Niño, Philos. Trans. R. Soc. B Biol. Sci., 373(1760), 20170406, doi:10.1098/rstb.2017.0406, 2018.

Cai, W., Santoso, A., Wang, G., Yeh, S.-W. W., An, S.-I. Il, Cobb, K. M., Collins, M., Guilyardi, E., Jin, F.-F. F., Kug, J.-S. S., Lengaigne, M., McPhaden, M. J., Takahashi, K., Timmermann, A., Vecchi, G., Watanabe, M. and Wu, L.: ENSO and greenhouse warming, Nat. Clim. Chang., 5(9), 849-859, doi:10.1038/nclimate2743, 2015.

Castro, A. O., Chen, J., Zang, C. S., Shekhar, A., Jimenez, J. C., Bhattacharjee, S., Kindu, M., Morales, V. H. and Rammig, A.: OCO-2 Solar-Induced Chlorophyll Fluorescence Variability across Ecoregions of the Amazon Basin and the Extreme Drought Effects of El Niño (2015-2016), Remote Sens., 12(7), 1202, doi:10.3390/rs12071202, 2020.

Coelho, C. A. S., Cavalcanti, I. A. F., Costa, S. M. S., Freitas, S. R., Ito, E. R., Luz, G., Santos, A. F., Nobre, C. A., 
https://doi.org/10.5194/bg-2020-425

Preprint. Discussion started: 2 December 2020

(c) Author(s) 2020. CC BY 4.0 License.

\section{(c) (1)}

500 Marengo, J. A. and Pezza, A. B.: Climate diagnostics of three major drought events in the Amazon and illustrations of their seasonal precipitation predictions, Meteorol. Appl., 19(2), 237-255, doi:10.1002/met.1324, 2012.

Compo, G. P., Sardeshmukh, P. D., Whitaker, J. S., Brohan, P., Jones, P. D. and McColl, C.: Independent confirmation of global land warming without the use of station temperatures, Geophys. Res. Lett., 40(12), 3170-3174, doi:10.1002/grl.50425, 2013.

505 Covey, C., Gleckler, P. J., Doutriaux, C., Williams, D. N., Dai, A., Fasullo, J., Trenberth, K. and Berg, A.: Metrics for the Diurnal Cycle of Precipitation: Toward Routine Benchmarks for Climate Models, J. Clim., 29(12), 4461-4471, doi:10.1175/JCLI-D-15-0664.1, 2016.

Dee, D. P., Uppala, S. M., Simmons, A. J., Berrisford, P., Poli, P., Kobayashi, S., Andrae, U., Balmaseda, M. A., Balsamo, G., Bauer, P., Bechtold, P., Beljaars, A. C. M., van de Berg, L., Bidlot, J., Bormann, N., Delsol, C., Dragani, R., Fuentes, M.,

510 Geer, A. J., Haimberger, L., Healy, S. B., Hersbach, H., Hólm, E. V., Isaksen, L., Kållberg, P., Köhler, M., Matricardi, M., McNally, A. P., Monge-Sanz, B. M., Morcrette, J.-J., Park, B.-K., Peubey, C., de Rosnay, P., Tavolato, C., Thépaut, J.-N. and Vitart, F.: The ERA-Interim reanalysis: configuration and performance of the data assimilation system, Q. J. R. Meteorol. Soc., 137(656), 553-597, doi:10.1002/qj.828, 2011.

Dirmeyer, P. A., Schlosser, C. A. and Brubaker, K. L.: Precipitation, Recycling, and Land Memory: An Integrated Analysis, J. Hydrometeorol., 10(1), 278-288, doi:10.1175/2008JHM1016.1, 2009.

Dirmeyer, P. A., Cash, B. A., Kinter, J. L., Jung, T., Marx, L., Satoh, M., Stan, C., Tomita, H., Towers, P., Wedi, N., Achuthavarier, D., Adams, J. M., Altshuler, E. L., Huang, B., Jin, E. K. and Manganello, J.: Simulating the diurnal cycle of rainfall in global climate models: resolution versus parameterization, Clim. Dyn., 39(1-2), 399-418, doi:10.1007/s00382011-1127-9, 2012.

Döll, P. and Lehner, B.: Validation of a new global 30-min drainage direction map, J. Hydrol., 258(1-4), 214-231, doi:10.1016/S0022-1694(01)00565-0, 2002.

van der Ent, R. J., Savenije, H. H. G., Schaefli, B. and Steele-Dunne, S. C.: Origin and fate of atmospheric moisture over continents, Water Resour. Res., 46(9), 1-12, doi:10.1029/2010WR009127, 2010.

Espinoza, J. C., Sörensson, A. A., Ronchail, J., Molina-Carpio, J., Segura, H., Gutierrez-Cori, O., Ruscica, R., Condom, T. and Wongchuig-Correa, S.: Regional hydro-climatic changes in the Southern Amazon Basin (Upper Madeira Basin) during the 1982-2017 period, J. Hydrol. Reg. Stud., 26(1), 100637, doi:10.1016/j.ejrh.2019.100637, 2019.

Esquivel-Muelbert, A., Baker, T. R., Dexter, K. G., Lewis, S. L., Brienen, R. J. W., Feldpausch, T. R., Lloyd, J., Monteagudo-Mendoza, A., Arroyo, L., Álvarez-Dávila, E., Higuchi, N., Marimon, B. S., Marimon-Junior, B. H., Silveira, M., Vilanova, E., Gloor, E., Malhi, Y., Chave, J., Barlow, J., Bonal, D., Davila Cardozo, N., Erwin, T., Fauset, S., Hérault, 530 B., Laurance, S., Poorter, L., Qie, L., Stahl, C., Sullivan, M. J. P., ter Steege, H., Vos, V. A., Zuidema, P. A., Almeida, E., Almeida de Oliveira, E., Andrade, A., Vieira, S. A., Aragão, L., Araujo-Murakami, A., Arets, E., Aymard C, G. A., Baraloto, 
https://doi.org/10.5194/bg-2020-425

Preprint. Discussion started: 2 December 2020

(c) Author(s) 2020. CC BY 4.0 License.

(c) (i)

C., Camargo, P. B., Barroso, J. G., Bongers, F., Boot, R., Camargo, J. L., Castro, W., Chama Moscoso, V., Comiskey, J., Cornejo Valverde, F., Lola da Costa, A. C., del Aguila Pasquel, J., Di Fiore, A., Fernanda Duque, L., Elias, F., Engel, J., Flores Llampazo, G., Galbraith, D., Herrera Fernández, R., Honorio Coronado, E., Hubau, W., Jimenez-Rojas, E., Lima, A. 535 J. N., Umetsu, R. K., Laurance, W., Lopez-Gonzalez, G., Lovejoy, T., Aurelio Melo Cruz, O., Morandi, P. S., Neill, D., Núñez Vargas, P., Pallqui Camacho, N. C., Parada Gutierrez, A., Pardo, G., Peacock, J., Peña-Claros, M., Peñuela-Mora, M. C., Petronelli, P., Pickavance, G. C., Pitman, N., Prieto, A., Quesada, C., Ramírez-Angulo, H., Réjou-Méchain, M., Restrepo Correa, Z., Roopsind, A., Rudas, A., Salomão, R., Silva, N., Silva Espejo, J., Singh, J., Stropp, J., Terborgh, J., Thomas, R., Toledo, M., Torres-Lezama, A., Valenzuela Gamarra, L., van de Meer, P. J., van der Heijden, G., et al.: Compositional response of Amazon forests to climate change, Glob. Chang. Biol., 25(1), 39-56, doi:10.1111/gcb.14413, 2019.

Forkel, M., Drüke, M., Thurner, M., Dorigo, W., Schaphoff, S., Thonicke, K., von Bloh, W. and Carvalhais, N.: Constraining modelled global vegetation dynamics and carbon turnover using multiple satellite observations, Sci. Rep., 9(1), 1-12, doi:10.1038/s41598-019-55187-7, 2019.

Funk, C., Peterson, P., Landsfeld, M., Pedreros, D., Verdin, J., Shukla, S., Husak, G., Rowland, J., Harrison, L., Hoell, A. and Michaelsen, J.: The climate hazards infrared precipitation with stations - A new environmental record for monitoring extremes, Sci. Data, 2, 1-21, doi:10.1038/sdata.2015.66, 2015.

Giardina, F., Konings, A. G., Kennedy, D., Alemohammad, S. H., Oliveira, R. S., Uriarte, M. and Gentine, P.: Tall Amazonian forests are less sensitive to precipitation variability, Nat. Geosci., 11(6), 405-409, doi:10.1038/s41561-0180133-5, 2018.

550 Giles, J. A., Ruscica, R. C. and Menéndez, C. G.: The diurnal cycle of precipitation over South America represented by five gridded datasets, Int. J. Climatol., 40(2), 668-686, doi:10.1002/joc.6229, 2020.

Di Giuseppe, F., Molteni, F. and Dutra, E.: Real-time correction of ERA-Interim monthly rainfall, Geophys. Res. Lett., 40(14), 3750-3755, doi:10.1002/grl.50670, 2013.

Gloor, M., Barichivich, J., Ziv, G., Brienen, R., Schöngart, J., Peylin, P., Ladvocat Cintra, B. B., Feldpausch, T., Phillips, O.

and Baker, J.: Recent Amazon climate as background for possible ongoing and future changes of Amazon humid forests, Global Biogeochem. Cycles, 29(9), 1384-1399, doi:10.1002/2014GB005080, 2015.

Golian, S., Javadian, M. and Behrangi, A.: On the use of satellite, gauge, and reanalysis precipitation products for drought studies, Environ. Res. Lett., 14(7), doi:10.1088/1748-9326/ab2203, 2019.

Grossiord, C., Buckley, T. N., Cernusak, L. A., Novick, K. A., Poulter, B., Siegwolf, R. T. W., Sperry, J. S. and McDowell,

N. G.: Plant responses to rising vapor pressure deficit, New Phytol., nph.16485, doi:10.1111/nph.16485, 2020.

Harris, I., Jones, P. D. D., Osborn, T. J. J. and Lister, D. H. H.: Updated high-resolution grids of monthly climatic observations - the CRU TS3.10 Dataset, Int. J. Climatol., 34(3), 623-642, doi:10.1002/joc.3711, 2014. 
https://doi.org/10.5194/bg-2020-425

Preprint. Discussion started: 2 December 2020

(c) Author(s) 2020. CC BY 4.0 License.

(c) (i)

Hubau, W., Lewis, S. L., Phillips, O. L., Affum-Baffoe, K., Beeckman, H., Cuní-Sanchez, A., Daniels, A. K., Ewango, C. E. N., Fauset, S., Mukinzi, J. M., Sheil, D., Sonké, B., Sullivan, M. J. P., Sunderland, T. C. H., Taedoumg, H., Thomas, S. C.,

565 White, L. J. T., Abernethy, K. A., Adu-Bredu, S., Amani, C. A., Baker, T. R., Banin, L. F., Baya, F., Begne, S. K., Bennett, A. C., Benedet, F., Bitariho, R., Bocko, Y. E., Boeckx, P., Boundja, P., Brienen, R. J. W., Brncic, T., Chezeaux, E., Chuyong, G. B., Clark, C. J., Collins, M., Comiskey, J. A., Coomes, D. A., Dargie, G. C., de Haulleville, T., Kamdem, M. N. D., Doucet, J.-L., Esquivel-Muelbert, A., Feldpausch, T. R., Fofanah, A., Foli, E. G., Gilpin, M., Gloor, E., Gonmadje, C., Gourlet-Fleury, S., Hall, J. S., Hamilton, A. C., Harris, D. J., Hart, T. B., Hockemba, M. B. N., Hladik, A., Ifo, S. A., Jeffery,

570 K. J., Jucker, T., Yakusu, E. K., Kearsley, E., Kenfack, D., Koch, A., Leal, M. E., Levesley, A., Lindsell, J. A., Lisingo, J., Lopez-Gonzalez, G., Lovett, J. C., Makana, J.-R., Malhi, Y., Marshall, A. R., Martin, J., Martin, E. H., Mbayu, F. M., Medjibe, V. P., Mihindou, V., Mitchard, E. T. A., Moore, S., Munishi, P. K. T., Bengone, N. N., Ojo, L., Ondo, F. E., Peh, K. S. H., Pickavance, G. C., Poulsen, A. D., Poulsen, J. R., Qie, L., Reitsma, J., Rovero, F., Swaine, M. D., Talbot, J., Taplin, J., Taylor, D. M., Thomas, D. W., Toirambe, B., Mukendi, J. T., Tuagben, D., Umunay, P. M., et al.: Asynchronous carbon sink saturation in African and Amazonian tropical forests, Nature, 579(7797), 80-87, doi:10.1038/s41586-020-2035-0, 2020.

Huffman, G. J., Bolvin, D. T., Nelkin, E. J., Wolff, D. B., Adler, R. F., Gu, G., Hong, Y., Bowman, K. P. and Stocker, E. F.: The TRMM Multisatellite Precipitation Analysis (TMPA): Quasi-Global, Multiyear, Combined-Sensor Precipitation Estimates at Fine Scales, J. Hydrometeorol., 8(1), 38-55, doi:10.1175/JHM560.1, 2007.

Jia, G., Shevliakova, E., Artaxo, P., de Noble-Ducoudre, N., Houghton, R., House, J., Kitajima, K., Lennard, C., Popp, A., 580 Sirin, R., Sukumar, R. and Verchot, L.: Land-climate interactions. In: Climate Change and Land: an IPCC special report on climate change, desertification, land degradation, sustainable land management, food security, and greenhouse gas fluxes in terrestrial ecosystems, [online] Available from: https://www.ipcc.ch/site/assets/uploads/sites/4/2019/11/05_Chapter-2.pdf, 2019.

Jiménez-Muñoz, J. C., Mattar, C., Barichivich, J., Santamaría-Artigas, A., Takahashi, K., Malhi, Y., Sobrino, J. A. and 585 Schrier, G. Van Der: Record-breaking warming and extreme drought in the Amazon rainforest during the course of El Niño 2015-2016, Sci. Rep., 6(1), 33130, doi:10.1038/srep33130, 2016.

Jimenez, J. C., Barichivich, J., Mattar, C., Takahashi, K., Santamaría-Artigas, A., Sobrino, J. A. and Malhi, Y.: Spatiotemporal patterns of thermal anomalies and drought over tropical forests driven by recent extreme climatic anomalies, Philos. Trans. R. Soc. B Biol. Sci., 373(1760), 20170300, doi:10.1098/rstb.2017.0300, 2018.

590 Jimenez, J. C., Marengo, J. A., Alves, L. M., Sulca, J. C., Takahashi, K., Ferrett, S. and Collins, M.: The role of ENSO flavours and TNA on recent droughts over Amazon forests and the Northeast Brazil region, Int. J. Climatol., (July), 1-20, doi:10.1002/joc.6453, 2019.

Konings, A. G. and Gentine, P.: Global variations in ecosystem-scale isohydricity, Glob. Chang. Biol., 23(2), 891-905, doi:10.1111/gcb.13389, 2017.

595 Lewis, S. L., Brando, P. M., Phillips, O. L., Van Der Heijden, G. M. F. and Nepstad, D.: The 2010 Amazon drought, Science (80-. )., 331(6017), 554, doi:10.1126/science.1200807, 2011. 
https://doi.org/10.5194/bg-2020-425

Preprint. Discussion started: 2 December 2020

(c) Author(s) 2020. CC BY 4.0 License.

(c) (i)

Maignan, F., Bréon, F.-M., Chevallier, F., Viovy, N., Ciais, P., Garrec, C., Trules, J. and Mancip, M.: Evaluation of a Global Vegetation Model using time series of satellite vegetation indices, Geosci. Model Dev., 4(4), 1103-1114, doi:10.5194/gmd4-1103-2011, 2011.

600 Malhi, Y., Roberts, J. T., Betts, R. A., Killeen, T. J., Li, W. and Nobre, C. A.: Climate Change, Deforestation, and the Fate of the Amazon, Science (80-. )., 319(5860), 169-172, doi:10.1126/science.1146961, 2008.

Malhi, Y., Aragao, L. E. O. C., Galbraith, D., Huntingford, C., Fisher, R., Zelazowski, P., Sitch, S., McSweeney, C. and Meir, P.: Exploring the likelihood and mechanism of a climate-change-induced dieback of the Amazon rainforest, Proc. Natl. Acad. Sci., 106(49), 20610-20615, doi:10.1073/pnas.0804619106, 2009.

605 Marengo, J. A. and Espinoza, J. C.: Extreme seasonal droughts and floods in Amazonia: Causes, trends and impacts, Int. J. Climatol., 36(3), 1033-1050, doi:10.1002/joc.4420, 2016.

Marengo, J. A., Nobre, C. A., Tomasella, J., Cardoso, M. F. and Oyama, M. D.: Hydro-climatic and ecological behaviour of the drought of Amazonia in 2005, Philos. Trans. R. Soc. B Biol. Sci., 363(1498), 1773-1778, doi:10.1098/rstb.2007.0015, 2008a.

610 Marengo, J. A., Nobre, C. A., Tomasella, J., Oyama, M. D., Sampaio de Oliveira, G., de Oliveira, R., Camargo, H., Alves, L. M. and Brown, I. F.: The Drought of Amazonia in 2005, J. Clim., 21(3), 495-516, doi:10.1175/2007JCLI1600.1, 2008 b.

Marengo, J. A., Tomasella, J., Alves, L. M., Soares, W. R. and Rodriguez, D. A.: The drought of 2010 in the context of historical droughts in the Amazon region, Geophys. Res. Lett., 38(12), n/a-n/a, doi:10.1029/2011GL047436, 2011.

Miralles, D. G., Gentine, P., Seneviratne, S. I. and Teuling, A. J.: Land-atmospheric feedbacks during droughts and 615 heatwaves: state of the science and current challenges, Ann. N. Y. Acad. Sci., 1436(1), 19-35, doi:10.1111/nyas.13912, 2019.

Muñoz-Sabater, J., Dutra, E., Balsamo, G., Boussetta, S., Zsoter, E., Albergel, C. and Agusti-Panareda, A.: ERA5-Land: an improved version of the ERA5 reanalysis land component, 2018.

Phillips, O. L., Aragao, L. E. O. C., Lewis, S. L., Fisher, J. B., Lloyd, J., Lopez-Gonzalez, G., Malhi, Y., Monteagudo, A., 620 Peacock, J., Quesada, C. A., van der Heijden, G., Almeida, S., Amaral, I., Arroyo, L., Aymard, G., Baker, T. R., Banki, O., Blanc, L., Bonal, D., Brando, P., Chave, J., de Oliveira, A. C. A., Cardozo, N. D., Czimczik, C. I., Feldpausch, T. R., Freitas, M. A., Gloor, E., Higuchi, N., Jimenez, E., Lloyd, G., Meir, P., Mendoza, C., Morel, A., Neill, D. A., Nepstad, D., Patino, S., Penuela, M. C., Prieto, A., Ramirez, F., Schwarz, M., Silva, J., Silveira, M., Thomas, A. S., Steege, H. t., Stropp, J., Vasquez, R., Zelazowski, P., Davila, E. A., Andelman, S., Andrade, A., Chao, K.-J., Erwin, T., Di Fiore, A., C., E. H., 625 Keeling, H., Killeen, T. J., Laurance, W. F., Cruz, A. P., Pitman, N. C. A., Vargas, P. N., Ramirez-Angulo, H., Rudas, A., Salamao, R., Silva, N., Terborgh, J. and Torres-Lezama, A.: Drought Sensitivity of the Amazon Rainforest, Science (80-. )., 323(5919), 1344-1347, doi:10.1126/science.1164033, 2009. 
https://doi.org/10.5194/bg-2020-425

Preprint. Discussion started: 2 December 2020

(c) Author(s) 2020. CC BY 4.0 License.

(c) (i)

Poulter, B., Frank, D. C., Hodson, E. L. and Zimmermann, N. E.: Impacts of land cover and climate data selection on understanding terrestrial carbon dynamics and the CO 2 airborne fraction, Biogeosciences, 8(8), 2027-2036, doi:10.5194/bg8-2027-2011, 2011.

von Randow, C., Manzi, A. O., Kruijt, B., de Oliveira, P. J., Zanchi, F. B., Silva, R. L., Hodnett, M. G., Gash, J. H. C., Elbers, J. A., Waterloo, M. J., Cardoso, F. L. and Kabat, P.: Comparative measurements and seasonal variations in energy and carbon exchange over forest and pasture in South West Amazonia, Theor. Appl. Climatol., 78(1-3), 5-26, doi:10.1007/s00704-004-0041-z, 2004.

635 Rao, K., Anderegg, W. R. L., Sala, A., Martínez-Vilalta, J. and Konings, A. G.: Satellite-based vegetation optical depth as an indicator of drought-driven tree mortality, Remote Sens. Environ., 227(February), 125-136, doi:10.1016/j.rse.2019.03.026, 2019.

Rifai, S. W., Li, S. and Malhi, Y.: Coupling of El Niño events and long-term warming leads to pervasive climate extremes in the terrestrial tropics, Environ. Res. Lett., 14(10), 105002, doi:10.1088/1748-9326/ab402f, 2019.

640 da Rocha, H. R., Goulden, M. L., Miller, S. D., Menton, M. C., Pinto, L. D. V. O., de Freitas, H. C. and e Silva Figueira, A. M.: SEASONALITY OF WATER AND HEAT FLUXES OVER A TROPICAL FOREST IN EASTERN AMAZONIA, Ecol. Appl., 14(sp4), 22-32, doi:10.1890/02-6001, 2004.

Rodell, M., Houser, P. R., Jambor, U., Gottschalck, J., Mitchell, K., Meng, C.-J., Arsenault, K., Cosgrove, B., Radakovich, J., Bosilovich, M., Entin, J. K., Walker, J. P., Lohmann, D. and Toll, D.: The Global Land Data Assimilation System, Bull. Am. Meteorol. Soc., 85(3), 381-394, doi:10.1175/BAMS-85-3-381, 2004.

Ruida, Z., Chen, X., Wang, Z., Lai, C. and Goddard, S.: Package scPDSI, [online] Available from: https://github.com/Sibada/scPDSI, 2018.

Ruiz-Vásquez, M., Arias, P. A., Martínez, J. A. and Espinoza, J. C.: Effects of Amazon basin deforestation on regional atmospheric circulation and water vapor transport towards tropical South America, Clim. Dyn., (0123456789), doi:10.1007/s00382-020-05223-4, 2020.

Schaphoff, S., Von Bloh, W., Rammig, A., Thonicke, K., Biemans, H., Forkel, M., Gerten, D., Heinke, J., Jägermeyr, J., Knauer, J., Langerwisch, F., Lucht, W., Müller, C., Rolinski, S. and Waha, K.: LPJmL4 - A dynamic global vegetation model with managed land - Part 1: Model description, Geosci. Model Dev., 11(4), 1343-1375, doi:10.5194/gmd-11-13432018, 2018.

655 Schneider, U., Becker, A., Finger, P., Anja, M.-C. and Markus, Z.: GPCC Full Data Monthly Version 2018.0 at $0.5^{\circ}$ : Monthly Land-Surface Precipitation from Rain-Gauges built on GTS-based and Historic Data, , doi:10.5676/DWD_GPCC/FD_M_V2018_050, 2018. 
https://doi.org/10.5194/bg-2020-425

Preprint. Discussion started: 2 December 2020

(c) Author(s) 2020. CC BY 4.0 License.

(c) (i)

Seiler, C., Hutjes, R. W. A., Kruijt, B. and Hickler, T.: The sensitivity of wet and dry tropical forests to climate change in Bolivia, J. Geophys. Res. Biogeosciences, 120(3), 399-413, doi:10.1002/2014JG002749, 2015.

660 Seto, S., Iguchi, T. and Meneghini, R.: Comparison of TRMM PR V6 and V7 focusing heavy rainfall, in 2011 IEEE International Geoscience and Remote Sensing Symposium, pp. 2582-2585, IEEE., 2011.

Sheffield, J., Goteti, G. and Wood, E. F.: Development of a 50-Year High-Resolution Global Dataset of Meteorological Forcings for Land Surface Modeling, J. Clim., 19(13), 3088-3111, doi:10.1175/JCLI3790.1, 2006.

Smith, B., Wårlind, D., Arneth, A., Hickler, T., Leadley, P., Siltberg, J. and Zaehle, S.: Implications of incorporating N cycling and $\mathrm{N}$ limitations on primary production in an individual-based dynamic vegetation model, Biogeosciences, 11(7), 2027-2054, doi:10.5194/bg-11-2027-2014, 2014.

Sörensson, A. A. and Ruscica, R. C.: Intercomparison and Uncertainty Assessment of Nine Evapotranspiration Estimates Over South America, Water Resour. Res., 54(4), 2891-2908, doi:10.1002/2017WR021682, 2018.

Toomey, M., D. A. Roberts, C. Still, M. L. Goulden, and J. P. McFadden (2011), Remotely sensed heat anomalies linked with Amazonian forest biomass declines, Geophys. Res. Lett., 38, L19704, doi:10.1029/2011GL049041.

Viovy, N.: CRUNCEP Version 7 - Atmospheric Forcing Data for the Community Land Model, [online] Available from: http://rda.ucar.edu/datasets/ds314.3/\%22, 2018.

Weedon, G. P., Gomes, S., Viterbo, P., Shuttleworth, W. J., Blyth, E., Österle, H., Adam, J. C., Bellouin, N., Boucher, O. and Best, M.: Creation of the WATCH Forcing Data and Its Use to Assess Global and Regional Reference Crop Evaporation over Land during the Twentieth Century, J. Hydrometeorol., 12(5), 823-848, doi:10.1175/2011JHM1369.1, 2011.

Weedon, G. P., Balsamo, G., Bellouin, N., Gomes, S., Best, M. J. and Viterbo, P.: Data methodology applied to ERAInterim reanalysis data, Water Resour. Res., 50, 7505-7514, doi:10.1002/2014WR015638.Received, 2014.

Wells, N., Goddard, S. and Hayes, M. J.: A Self-Calibrating Palmer Drought Severity Index, J. Clim., 17(12), 2335-2351, doi:10.1175/1520-0442(2004)017<2335:ASPDSI>2.0.CO;2, 2004.

680 Willmott, C. J., Rowe, C. M. and Philpot, W. D.: Small-Scale Climate Maps: A Sensitivity Analysis of Some Common Assumptions Associated with Grid-Point Interpolation and Contouring, Am. Cartogr., 12(1), 5-16, doi:10.1559/152304085783914686, 1985.

Yang, H., Piao, S., Zeng, Z., Ciais, P., Yin, Y., Friedlingstein, P., Sitch, S., Ahlström, A., Guimberteau, M., Huntingford, C., Levis, S., Levy, P. E., Huang, M., Li, Y., Li, X., Lomas, M. R., Peylin, P., Poulter, B., Viovy, N., Zaehle, S., Zeng, N., Zhao, 
https://doi.org/10.5194/bg-2020-425

Preprint. Discussion started: 2 December 2020

(c) Author(s) 2020. CC BY 4.0 License.

(c) (1)

685 F. and Wang, L.: Multicriteria evaluation of discharge simulation in Dynamic Global Vegetation Models, J. Geophys. Res. Atmos., 120(15), 7488-7505, doi:10.1002/2015JD023129, 2015.

Yang, J., Tian, H., Pan, S., Chen, G., Zhang, B. and Dangal, S.: Amazon drought and forest response: Largely reduced forest photosynthesis but slightly increased canopy greenness during the extreme drought of 2015/2016, Glob. Chang. Biol., 24(5), 1919-1934, doi:10.1111/gcb.14056, 2018.

690 Zang, C. S., Buras, A., Esquivel-Muelbert, A., Jump, A. S., Rigling, A. and Rammig, A.: Standardized drought indices in ecological research: Why one size does not fit all, Glob. Chang. Biol., 26(2), 322-324, doi:10.1111/gcb.14809, 2020.

Zemp, D. C., Schleussner, C.-F., Barbosa, H. M. J., van der Ent, R. J., Donges, J. F., Heinke, J., Sampaio, G. and Rammig, A.: On the importance of cascading moisture recycling in South America, Atmos. Chem. Phys., 14(23), 13337-13359, doi:10.5194/acp-14-13337-2014, 2014.

695 Zemp, D. C., Schleussner, C.-F., Barbosa, H. M. J. and Rammig, A.: Deforestation effects on Amazon forest resilience, Geophys. Res. Lett., 44(12), 6182-6190, doi:10.1002/2017GL072955, 2017a.

Zemp, D. C., Schleussner, C.-F., Barbosa, H. M. J., Hirota, M., Montade, V., Sampaio, G., Staal, A., Wang-Erlandsson, L. and Rammig, A.: Self-amplified Amazon forest loss due to vegetation-atmosphere feedbacks, Nat. Commun., 8(1), 14681, doi:10.1038/ncomms14681, 2017b.

700 Zeng, N., Yoon, J.-H., Marengo, J. A., Subramaniam, A., Nobre, C. A., Mariotti, A. and Neelin, J. D.: Causes and impacts of the 2005 Amazon drought, Environ. Res. Lett., 3(1), 014002, doi:10.1088/1748-9326/3/1/014002, 2008.

Ziese, M., Schneider, U., Meyer-Christoffer, A., Schamm, K., Vido, J., Finger, P., Bissolli, P., Pietzsch, S. and Becker, A.: The GPCC Drought Index - a new, combined and gridded global drought index, Earth Syst. Sci. Data, 6(2), 285-295, doi:10.5194/essd-6-285-2014, 2014. 
https://doi.org/10.5194/bg-2020-425

Preprint. Discussion started: 2 December 2020

(c) Author(s) 2020. CC BY 4.0 License.

(c) (i)

\section{Figures}
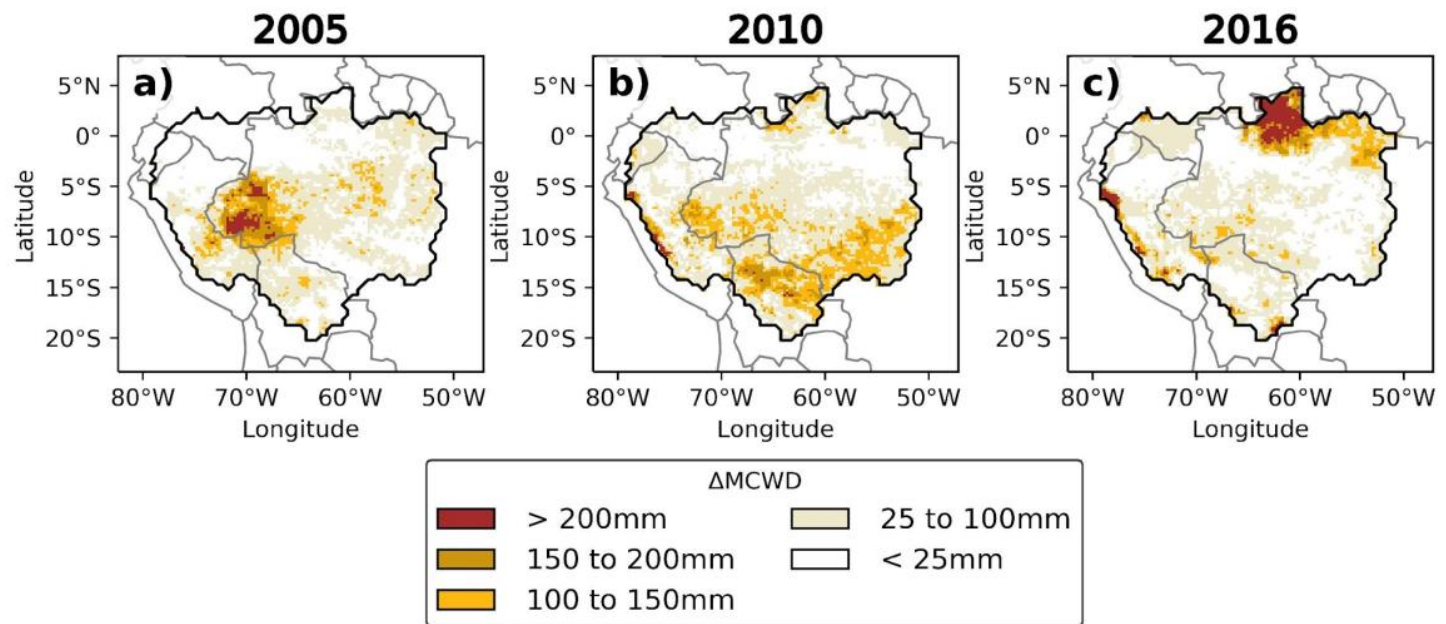

Figure 1: (a-c) Anomalies of $\triangle \mathrm{MCWD}$ (from October to September) as an indicator for drought stress in the Amazon Basin during the record-breaking drought events in 2005, 2010 and 2015/16 based on the TR7 dataset. 
https://doi.org/10.5194/bg-2020-425

Preprint. Discussion started: 2 December 2020

(c) Author(s) 2020. CC BY 4.0 License.

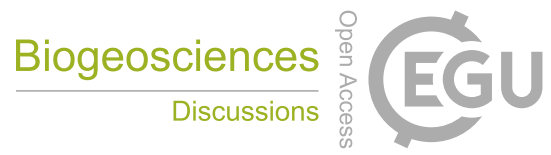

(c) (i)
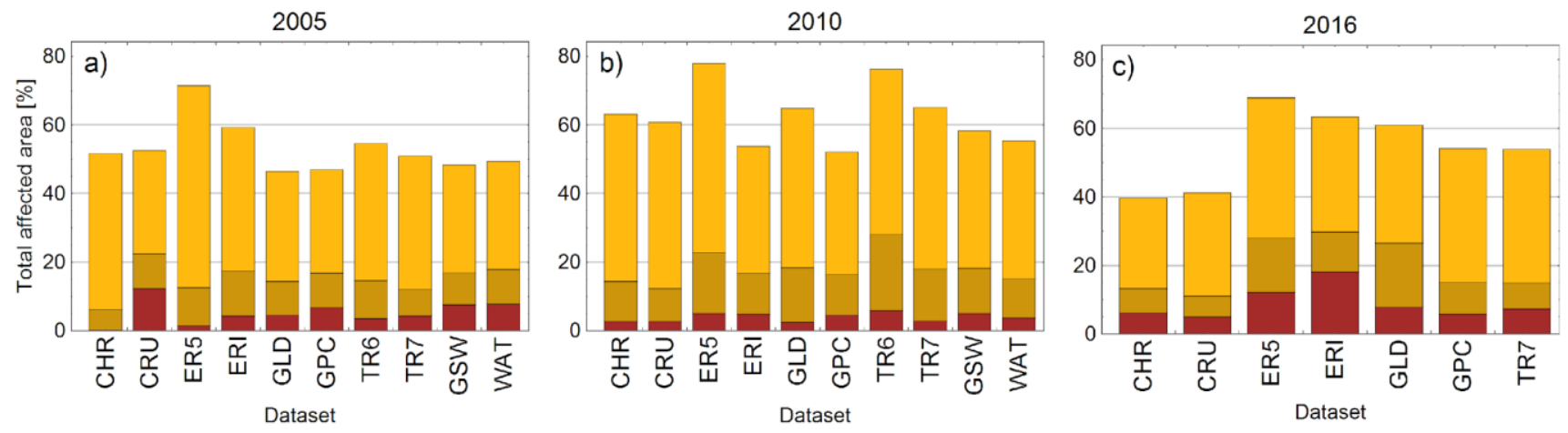

\begin{tabular}{|lc|}
\hline & Drought stress indication \\
$\square$ moderate & $(-100 \mathrm{~mm}<\triangle M C W D<-25 \mathrm{~mm})$ \\
$\square$ severe & $(-150 \mathrm{~mm}<\Delta M C W D<-100 \mathrm{~mm})$ \\
$\square$ extreme & $(\triangle \mathrm{MCWD}<-150 \mathrm{~mm})$ \\
\hline
\end{tabular}

Figure 2: Total area of the Amazon basin affected by drought stress (\%) according to $\triangle \mathrm{MCWD}$ for each of the precipitation datasets (for abbreviations see Tab. 1). Displayed are the three drought events (a) 2005, (b) 2010 and (c) 2016. The total area representing the Amazon basin in our study is 5.94 million km². For absolute area affected, see Tab. 2 and 3. 
https://doi.org/10.5194/bg-2020-425

Preprint. Discussion started: 2 December 2020

(c) Author(s) 2020. CC BY 4.0 License.
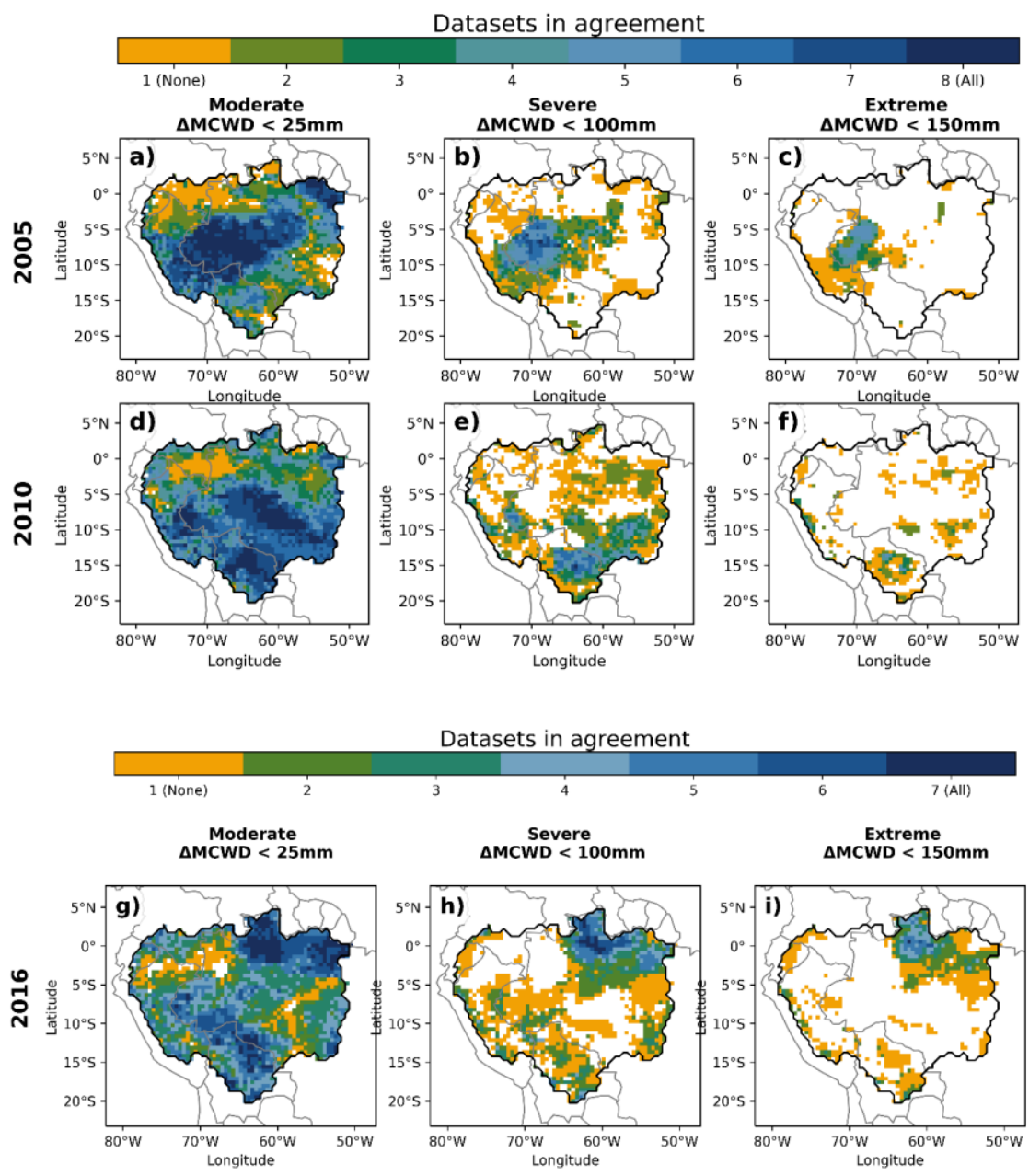

Figure 3: Agreement of precipitation datasets on drought area as identified by $\triangle M C W D$ anomalies. In columns, different levels of drought severity are displayed and rows show the different drought years 2005 (a-c), 2010 (d-f) and 2016 (g-i). The colors indicate the number of datasets that agree on a specific drought level in a given pixel. Drought severity levels are defined as moderate $(\triangle \mathrm{MCWD}<-25 \mathrm{~mm})$, severe $(\triangle \mathrm{MCWD}<-100 \mathrm{~mm})$ and extreme $(\triangle \mathrm{MCWD}<-150 \mathrm{~mm})$. Orange pixels indicate areas where only dataset shows the respective drought stress (No agreement = "None"). White pixels represent areas where no dataset shows any drought signal. Note that in a-f, TR6 and GSW were excluded, as they were either very similar to its successor (TR7) and or due to a similar reanalysis procedure (WAT). In g-i, only seven datasets were included, which cover the full time period until 2016. 
https://doi.org/10.5194/bg-2020-425

Preprint. Discussion started: 2 December 2020

(c) Author(s) 2020. CC BY 4.0 License.

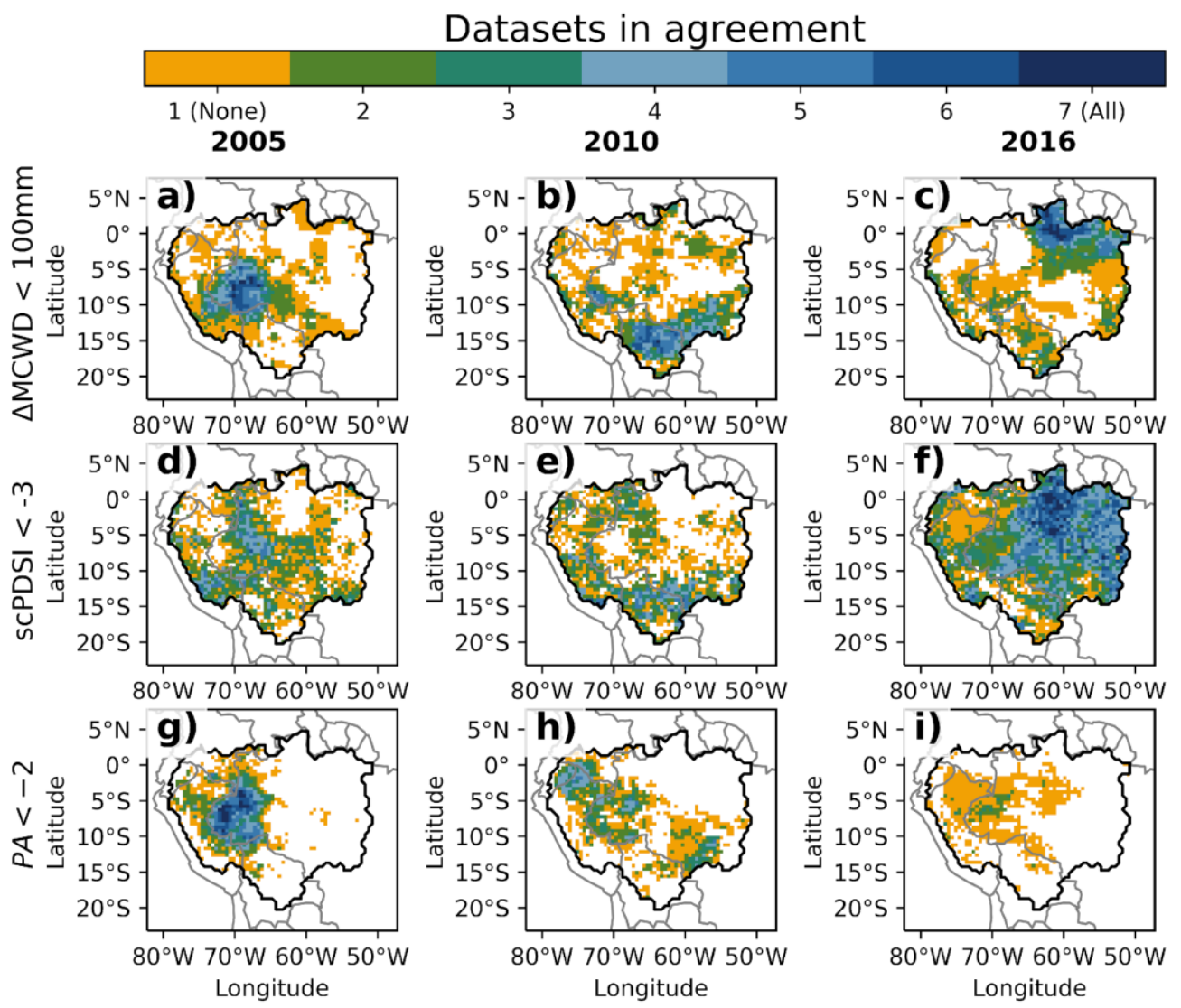

Figure 4: Agreement of precipitation datasets on drought area as identified by different drought metrics. Comparison of the

Amazon drought events in 2005, 2010 and 2016 (columns) vs three different drought indexes (rows): $\triangle \mathrm{MCWD}$ (a-c), scPDSI (d-f) and rainfall anomaly (g-i). Only the area affected by severe drought stress is displayed, severe drought is defined differently for each of the drought indices: $\triangle \mathrm{MCWD}$ less than $-100 \mathrm{~mm}$, scPDSI less than -3 and RA less than -2 . Orange pixels indicate areas where only one dataset shows the respective drought stress ("None"). White pixels represent areas where no dataset shows any drought signal. 

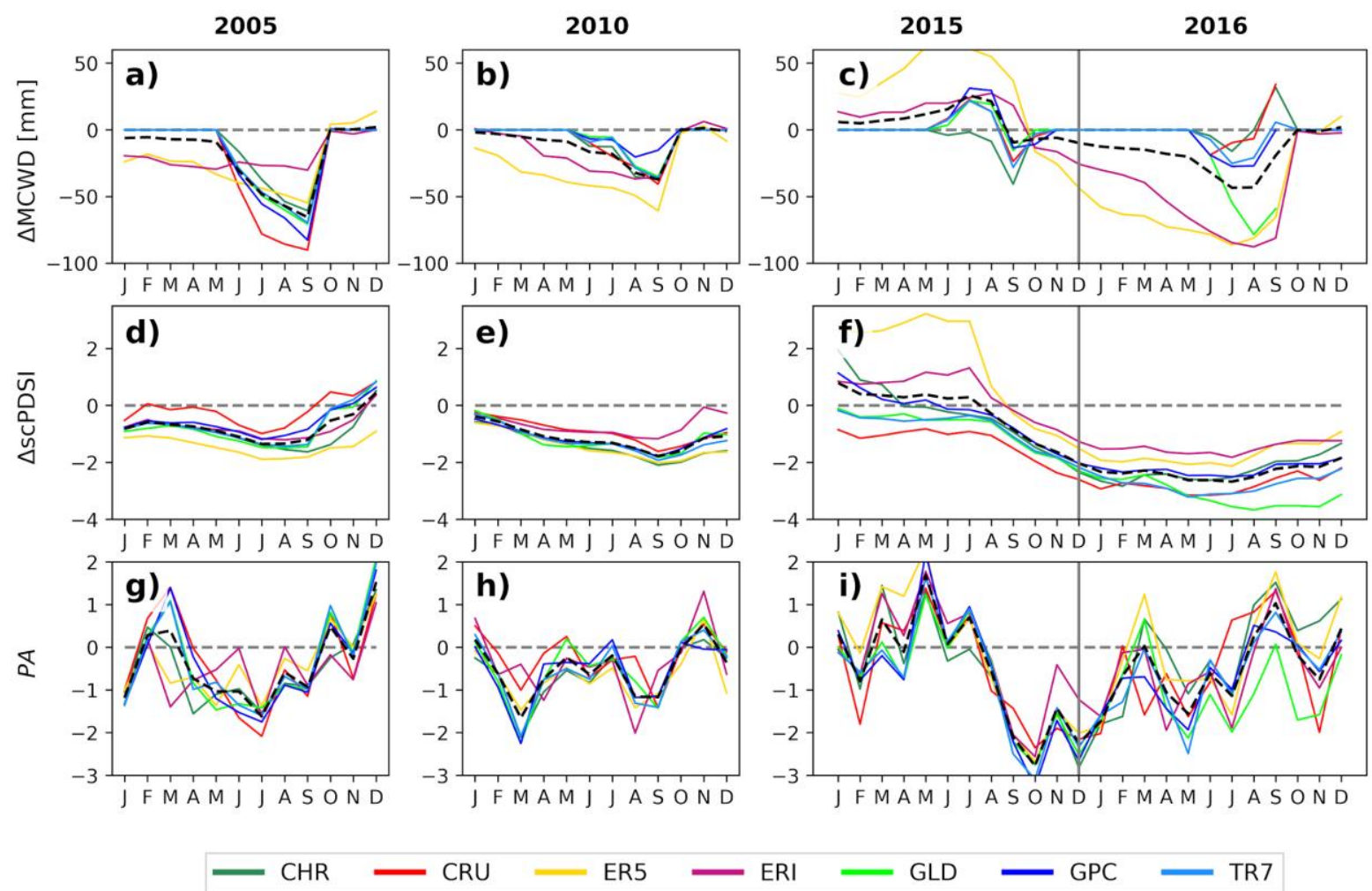

CRU

ER5

ERI

GLD

GPC

TR7

Figure 5: Monthly development of the Amazon drought events in 2005, 2010 and 2016 (columns) as described by the three different drought indices (rows): $\triangle \mathrm{MCWD}$ (a-c), scPDSI (d-f) and rainfall anomaly (RA, g-i). Colored lines indicate the different precipitation datasets (for abbreviations see Tab. 1). RA is estimated for each month. 
https://doi.org/10.5194/bg-2020-425

Preprint. Discussion started: 2 December 2020

(c) Author(s) 2020. CC BY 4.0 License.

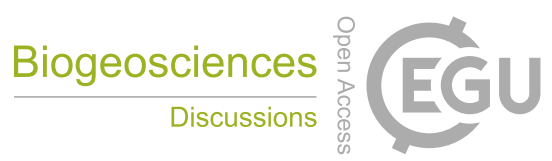

(c) (1)

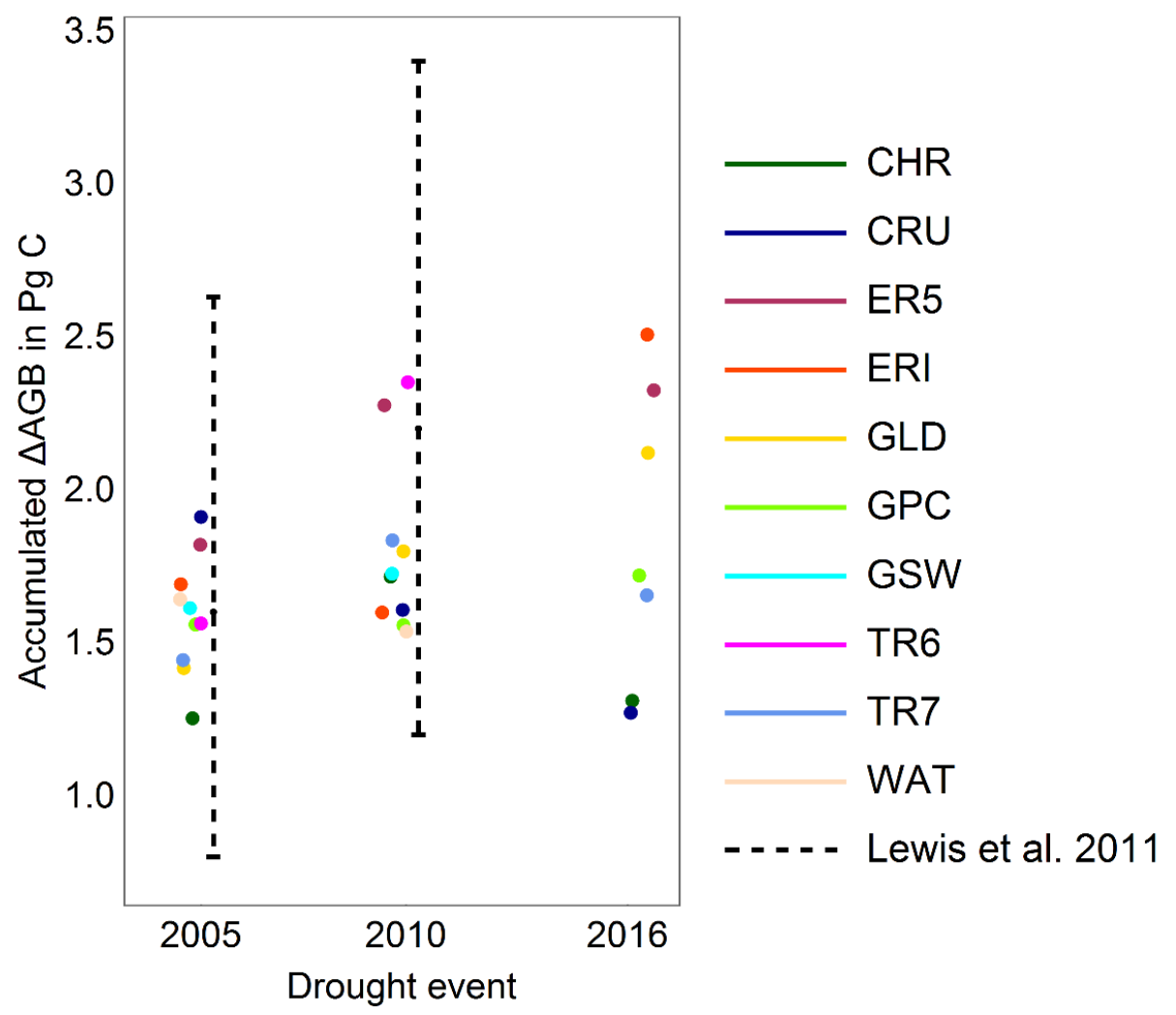

750 Figure 6: Impact of the 2005, 2010 and 2016 drought event on aboveground carbon biomass (AGB in Pg C). Biomass loss was calculated for each of the precipitation datasets (colored dots, for abbreviations see Tab. 1) based on a linear relation between biomass loss and $\triangle \mathrm{MCWD}$ as proposed by Lewis 
https://doi.org/10.5194/bg-2020-425

Preprint. Discussion started: 2 December 2020

(c) Author(s) 2020. CC BY 4.0 License.

\section{Tables}

755 Table 1: Overview of the 10 precipitation datasets used in our study. Columns show the name of the dataset, the official abbreviation, the short abbreviation used in here, the spatial and temporal resolution and the references.

\begin{tabular}{|c|c|c|c|c|c|}
\hline $\begin{array}{l}\text { Precipitation } \\
\text { dataset }\end{array}$ & Abbreviation & $\begin{array}{l}\text { Abbreviation } \\
\text { (short) }\end{array}$ & Details & Resolutions & References \\
\hline $\begin{array}{l}\text { Climate Hazards } \\
\text { group Infrared } \\
\text { Precipitation with } \\
\text { Stations }\end{array}$ & CHIRPS & CHR & $\begin{array}{l}\text { quasi-global }\left(50^{\circ} \mathrm{S}-\right. \\
\left.50^{\circ} \mathrm{N}\right) \\
\text { precipitation-only } \\
\text { merged product, } \\
\text { based on global } \\
\text { climatology, } \\
\text { satellite estimates } \\
\text { and in situ } \\
\text { observations. }\end{array}$ & $\begin{array}{l}\text { high resolution } \\
\left(0.05^{\circ}\right), \quad \text { daily, } \\
\text { pentadal, and } \\
\text { monthly }\end{array}$ & $\begin{array}{l}\text { Funk et al., } \\
2015\end{array}$ \\
\hline $\begin{array}{l}\text { Tropical Rainfall } \\
\text { Measurement } \\
\text { Misson }\end{array}$ & $\begin{array}{l}\text { TRMM v6 } \\
\text { 3b43 }\end{array}$ & TR6 & $\begin{array}{l}\text { quasi-global }\left(50^{\circ} \mathrm{S}-\right. \\
\left.50^{\circ} \mathrm{N}\right)\end{array}$ & $\begin{array}{l}\text { Quarter degree } \\
\text { resolution }\left(0.25^{\circ}\right) \\
\text { daily, pentadal, } \\
\text { and monthly }\end{array}$ & $\begin{array}{l}\text { Huffman et al., } \\
2007\end{array}$ \\
\hline \multirow[t]{2}{*}{$\begin{array}{l}\text { Tropical Rainfall } \\
\text { Measurement } \\
\text { Misson }\end{array}$} & $\begin{array}{l}\text { TRMM v7 } \\
\text { 3B43 }\end{array}$ & TR7 & $\begin{array}{l}\text { quasi-global }\left(50^{\circ} \mathrm{S}-\right. \\
\left.50^{\circ} \mathrm{N}\right)\end{array}$ & $\begin{array}{l}\text { Quarter degree } \\
\text { resolution }\left(0.25^{\circ}\right) \text {, } \\
\text { daily, pentadal, } \\
\text { and monthly }\end{array}$ & $\begin{array}{l}\text { Huffman et al., } \\
2007\end{array}$ \\
\hline & $\begin{array}{l}\text { CRU_NCEP } \\
\text { V8 }\end{array}$ & $\mathrm{CNP}$ & global & $\begin{array}{l}\text { Half degree } \\
\text { resolution }\left(0.5^{\circ}\right), \\
\text { daily, pentadal } \\
\text { and monthly }\end{array}$ & $\begin{array}{l}\text { Viovy et al., } \\
2017\end{array}$ \\
\hline ERA_Interim & $\begin{array}{l}\text { ERA_Interim } \\
\text { SFC12_03_T } \\
\text { P_228 }\end{array}$ & ERI & global & $\begin{array}{l}0.75^{\circ} \quad \text { daily, } \\
\text { pentadal, and } \\
\text { monthly }\end{array}$ & $\begin{array}{l}\text { Dee et al., } \\
2011\end{array}$ \\
\hline
\end{tabular}




\begin{tabular}{|c|c|c|c|c|c|}
\hline ERA5 & & ER5 & global & $\begin{array}{l}\text { Quarter degree } \\
\text { resolution }\left(0.25^{\circ}\right) \text {, } \\
\text { sub-daily, daily, } \\
\text { monthly }\end{array}$ & $\begin{array}{l}\text { Albergel et al., } \\
2018\end{array}$ \\
\hline $\begin{array}{l}\text { Global Land Data } \\
\text { Assimilation } \\
\text { System }\end{array}$ & GLDAS 2.1 & GLD & global & $\begin{array}{l}\text { Quarter degree } \\
\text { resolution }\left(0.25^{\circ}\right) \text {, } \\
\text { daily, pentadal, } \\
\text { and monthly }\end{array}$ & $\begin{array}{l}\text { Rodell et al., } \\
2004\end{array}$ \\
\hline $\begin{array}{l}\text { Global } \\
\text { Precipitation } \\
\text { Climatology } \\
\text { Centre at } \\
\text { Deutscher } \\
\text { Wetterdienst }\end{array}$ & GPCC 2018 & GPC & global & $\begin{array}{l}\text { Quarter degree } \\
\text { resolution }\left(0.25^{\circ}\right) \text {, } \\
\text { monthly }\end{array}$ & $\begin{array}{l}\text { Schneider et } \\
\text { al., } 2018\end{array}$ \\
\hline $\begin{array}{lr}\text { Global } & \text { Soil } \\
\text { Wetness } & \text { Project } \\
\text { Phase } 3 & \end{array}$ & GSWP3 & GSW & global & $\begin{array}{l}\text { Half degree } \\
\text { resolution }\left(0.5^{\circ}\right) \text {, } \\
\text { daily, monthly }\end{array}$ & $\begin{array}{l}\text { H. Kim et al. } \\
\text { n.d.; } \\
\underline{\text { http://hydro.iis }} \\
\underline{\text { u- }} \\
\underline{\text { tokyo.ac.jp/GS }} \\
\underline{\text { WP3/index.ht }} \\
\underline{\text { ml }}\end{array}$ \\
\hline $\begin{array}{l}\text { WATCH Forcing } \\
\text { Data (WFD) + } \\
\text { WATCH Forcing } \\
\text { Data } \\
\text { methodology } \\
\text { applied to ERA- } \\
\text { Interim data } \\
\text { (WFDEI) }\end{array}$ & $\begin{array}{l}\text { WATCH_W } \\
\text { FDEI }\end{array}$ & WAT & global & $\begin{array}{l}\text { Half degree } \\
\text { resolution }\left(0.5^{\circ}\right) \text {, } \\
\text { daily, monthly }\end{array}$ & $\begin{array}{l}\text { Weedon et al., } \\
2011,2014\end{array}$ \\
\hline
\end{tabular}


Table 2: Total area affected by drought stress in million $\mathbf{k m}^{2}$ (and \%) by drought index (MCWD, scPDSI and RAI) and intensity (moderate, severe and extreme) across the 10 datasets evaluated in our study (rows) for the years 2005 and 2010.

\begin{tabular}{|c|c|c|c|c|c|c|c|}
\hline & & \multicolumn{6}{|c|}{ Year } \\
\hline & & 2005 & 2005 & 2005 & 2010 & 2010 & 2010 \\
\hline Metric & Dataset & $\begin{array}{l}\triangle M C W D< \\
-150 \mathrm{~mm} \\
\text { (extreme) }\end{array}$ & $\begin{array}{l}\triangle M C W D< \\
-100 m m \\
\text { (severe) }\end{array}$ & $\begin{array}{l}\triangle M C W D< \\
-25 m m \\
\text { (moderate) }\end{array}$ & $\begin{array}{l}M C W D< \\
-150 \mathrm{~mm} \\
\text { (extreme) }\end{array}$ & $\begin{array}{l}\triangle M C W D< \\
-100 m m \\
\text { (severe) }\end{array}$ & $\begin{array}{l}\triangle M C W D< \\
-25 m m \\
\text { (moderate) }\end{array}$ \\
\hline$\triangle \mathrm{MCWD}$ & CHR & $0.0(0 \%)$ & $0.4(6 \%)$ & $3.1(52 \%)$ & $0.2(3 \%)$ & $0.9(14 \%)$ & $3.8(63 \%)$ \\
\hline$\triangle \mathrm{MCWD}$ & CRU & $0.7(12 \%)$ & $1.3(22 \%)$ & $3.1(53 \%)$ & $0.2(3 \%)$ & $0.7(12 \%)$ & $3.6(61 \%)$ \\
\hline$\triangle \mathrm{MCWD}$ & ER5 & $0.1(2 \%)$ & $0.7(13 \%)$ & $4.2(71 \%)$ & $0.3(5 \%)$ & $1.3(23 \%)$ & $4.6(78 \%)$ \\
\hline$\triangle \mathrm{MCWD}$ & ERI & $0.3(4 \%)$ & 1. $(17 \%)$ & $3.5(59 \%)$ & $0.3(5 \%)$ & 1. (17\%) & $3.2(54 \%)$ \\
\hline$\triangle \mathrm{MCWD}$ & GLD & $0.3(5 \%)$ & $0.9(14 \%)$ & $2.8(46 \%)$ & $0.1(2 \%)$ & $1.1(18 \%)$ & $3.9(65 \%)$ \\
\hline$\triangle \mathrm{MCWD}$ & GPC & $0.4(7 \%)$ & 1. $(17 \%)$ & $2.8(47 \%)$ & $0.3(5 \%)$ & $1.0(16 \%)$ & $3.1(52 \%)$ \\
\hline$\triangle \mathrm{MCWD}$ & TR6 & $0.2(4 \%)$ & $0.9(15 \%)$ & $3.2(55 \%)$ & $0.4(6 \%)$ & $1.7(28 \%)$ & $4.5(76 \%)$ \\
\hline$\triangle \mathrm{MCWD}$ & TR7 & $0.3(4 \%)$ & $0.7(12 \%)$ & 3. $(51 \%)$ & $0.2(3 \%)$ & $1.1(18 \%)$ & $3.9(65 \%)$ \\
\hline$\triangle \mathrm{MCWD}$ & GSW & $0.5(8 \%)$ & $1.0(17 \%)$ & $2.9(48 \%)$ & $0.3(5 \%)$ & $1.1(18 \%)$ & $3.5(58 \%)$ \\
\hline$\triangle \mathrm{MCWD}$ & WAT & $0.5(8 \%)$ & $1.1(18 \%)$ & $2.9(49 \%)$ & $0.2(4 \%)$ & $0.9(15 \%)$ & $3.3(55 \%)$ \\
\hline & & $\begin{array}{l}S C P D S I< \\
-4 \\
\text { (extreme) }\end{array}$ & $\begin{array}{l}S c P D S I< \\
-3 \\
\text { (severe) }\end{array}$ & $\begin{array}{l}s c P D S I< \\
-2 \\
\text { (moderate) }\end{array}$ & $\begin{array}{l}S C P D S I< \\
-4 \\
\text { (extreme) }\end{array}$ & $\begin{array}{l}s c P D S I< \\
-3 \\
\text { (severe) }\end{array}$ & $\begin{array}{l}s c P D S I< \\
-2 \\
(\text { moderate) }\end{array}$ \\
\hline scPDSI & CHR & $0.2(3 \%)$ & $1.2(20 \%)$ & $2.5(42 \%)$ & $0.2(3 \%)$ & 2. $(34 \%)$ & $3.2(55 \%)$ \\
\hline scPDSI & CRU & $0.3(4 \%)$ & $1.5(26 \%)$ & $2.3(38 \%)$ & $0.1(2 \%)$ & 2. $(33 \%)$ & $3.1(52 \%)$ \\
\hline scPDSI & ER5 & $0.1(1 \%)$ & $1.1(18 \%)$ & $2.8(46 \%)$ & $0.1(1 \%)$ & $1.6(27 \%)$ & $3.1(52 \%)$ \\
\hline scPDSI & ERI & $0.0(1 \%)$ & $0.8(13 \%)$ & $1.7(29 \%)$ & $0.0(1 \%)$ & $1.2(20 \%)$ & $2.1(35 \%)$ \\
\hline scPDSI & GLD & $0.2(3 \%)$ & $1.0(16 \%)$ & $1.9(32 \%)$ & $0.2(3 \%)$ & $2.9(50 \%)$ & $4.2(71 \%)$ \\
\hline scPDSI & GPC & $0.1(2 \%)$ & $1.5(25 \%)$ & $2.6(43 \%)$ & $0.1(3 \%)$ & $1.9(32 \%)$ & 3. $(51 \%)$ \\
\hline scPDSI & TR6 & $0.3(5 \%)$ & $1.5(25 \%)$ & $2.8(48 \%)$ & $0.2(3 \%)$ & $1.9(32 \%)$ & $3.2(54 \%)$ \\
\hline scPDSI & TR7 & $0.3(5 \%)$ & $1.5(25 \%)$ & $2.8(48 \%)$ & $0.2(3 \%)$ & $1.9(32 \%)$ & $3.2(54 \%)$ \\
\hline scPDSI & GSW & $0.2(3 \%)$ & $1.6(26 \%)$ & $2.6(44 \%)$ & $0.2(3 \%)$ & $1.8(31 \%)$ & $3.1(52 \%)$ \\
\hline scPDSI & WAT & $0.2(3 \%)$ & $1.5(26 \%)$ & $2.6(44 \%)$ & $0.2(3 \%)$ & $1.8(30 \%)$ & 3. $(51 \%)$ \\
\hline
\end{tabular}




\begin{tabular}{|l|l|l|l|l|l|l|l|}
\hline & & $\begin{array}{l}R A<-3 \\
(\text { extreme) }\end{array}$ & $\begin{array}{l}R A<-2 \\
(\mathbf{s e v e r e})\end{array}$ & $\begin{array}{l}R A<-1 \\
(\text { moderate) }\end{array}$ & $\begin{array}{l}R A<-3 \\
(\text { extreme) }\end{array}$ & $\begin{array}{l}R A<-2 \\
\text { (severe) }\end{array}$ & $\begin{array}{l}R A<-1 \\
\text { (moderate) }\end{array}$ \\
\hline RA & CHR & $0.3(6 \%)$ & $1.2(20 \%)$ & $3.1(52 \%)$ & $0.2(3 \%)$ & $1 .(17 \%)$ & $3.6(60 \%)$ \\
\hline RA & CRU & $0.1(2 \%)$ & $0.6(9 \%)$ & $1.8(29 \%)$ & $0.1(1 \%)$ & $1 .(17 \%)$ & $3 .(50 \%)$ \\
\hline RA & ER5 & $0.3(4 \%)$ & $1.1(18 \%)$ & $2.9(49 \%)$ & $0.4(6 \%)$ & $1.7(28 \%)$ & $4.2(71 \%)$ \\
\hline RA & ERI & $0.6(10 \%)$ & $1.1(18 \%)$ & $2.5(42 \%)$ & $0.2(3 \%)$ & $1.0(16 \%)$ & $2.7(45 \%)$ \\
\hline RA & GLD & $0.2(4 \%)$ & $0.7(12 \%)$ & $1.7(29 \%)$ & $0.6(9 \%)$ & $1.2(21 \%)$ & $3.4(57 \%)$ \\
\hline RA & GPC & $0.2(4 \%)$ & $0.7(11 \%)$ & $2.2(36 \%)$ & $0.1(2 \%)$ & $0.7(12 \%)$ & $2.7(46 \%)$ \\
\hline RA & TR6 & $0.1(2 \%)$ & $0.6(11 \%)$ & $2.4(41 \%)$ & $0.1(2 \%)$ & $1.3(22 \%)$ & $3.7(63 \%)$ \\
\hline RA & TR7 & $0.2(3 \%)$ & $0.9(15 \%)$ & $2.8(47 \%)$ & $0.2(4 \%)$ & $1.2(20 \%)$ & $3.3(56 \%)$ \\
\hline RA & GSW & $0.2(4 \%)$ & $0.7(11 \%)$ & $2.1(36 \%)$ & $0.2(3 \%)$ & $0.9(16 \%)$ & $3.1(52 \%)$ \\
\hline RA & WAT & $0.3(4 \%)$ & $0.7(12 \%)$ & $2.2(37 \%)$ & $0.1(2 \%)$ & $0.8(13 \%)$ & $2.8(47 \%)$ \\
\hline
\end{tabular}

765 Table 3: Total area affected by drought in million $\mathrm{km}^{2}$ (and \%) by drought index (MCWD, scPDSI and RAI) and intensity (moderate, severe and extreme) across the 10 datasets evaluated in this study (rows) for the year 2016. TR6, GSW and WAT are missing from this calculation as their timespan ends before 2016.

\begin{tabular}{|c|c|c|c|c|}
\hline & & 2016 & 2016 & 2016 \\
\hline Metric & Dataset & $\begin{array}{c}\triangle M C W D \\
<-150 \mathrm{~mm} \\
\text { (extreme) }\end{array}$ & $\begin{array}{l}\quad \triangle M C W D \\
<-100 \mathrm{~mm} \\
\text { (severe) }\end{array}$ & $\begin{array}{c}\triangle M C W D \\
<-25 \mathrm{~mm} \\
\text { (moderate) }\end{array}$ \\
\hline$\triangle \mathrm{MCWD}$ & CHR & $0.4(6 \%)$ & $0.8(13 \%)$ & $2.4(40 \%)$ \\
\hline$\triangle \mathrm{MCWD}$ & CRU & $0.3(5 \%)$ & $0.7(11 \%)$ & $2.4(41 \%)$ \\
\hline$\triangle \mathrm{MCWD}$ & ER5 & $0.7(12 \%)$ & $1.7(28 \%)$ & $4.1(69 \%)$ \\
\hline$\triangle \mathrm{MCWD}$ & ERI & $1.1(18 \%)$ & $1.8(30 \%)$ & $3.8(63 \%)$ \\
\hline$\triangle \mathrm{MCWD}$ & GLD & $0.5(8 \%)$ & $1.6(27 \%)$ & $3.6(61 \%)$ \\
\hline$\triangle \mathrm{MCWD}$ & GPC & $0.3(6 \%)$ & $0.9(15 \%)$ & $3.2(54 \%)$ \\
\hline$\triangle \mathrm{MCWD}$ & TR7 & $0.4(7 \%)$ & $0.9(15 \%)$ & $3.2(54 \%)$ \\
\hline & & $\begin{array}{l}s c P D S I<-4 \\
\text { (extreme) }\end{array}$ & $\begin{array}{l}s c P D S I<-3 \\
\text { (severe) }\end{array}$ & $\begin{array}{l}S c P D S I<-2 \\
\text { (moderate) }\end{array}$ \\
\hline scPDSI & CHR & $0.3(4 \%)$ & $2.3(38 \%)$ & $3.3(56 \%)$ \\
\hline scPDSI & CRU & $0.3(5 \%)$ & $2.6(45 \%)$ & $3.7(62 \%)$ \\
\hline
\end{tabular}


https://doi.org/10.5194/bg-2020-425

Preprint. Discussion started: 2 December 2020

(C) Author(s) 2020. CC BY 4.0 License.

\begin{tabular}{|l|l|l|l|l|}
\hline scPDSI & ER5 & $0.3(5 \%)$ & $2.1(35 \%)$ & $2.9(48 \%)$ \\
\hline scPDSI & ERI & $0.5(9 \%)$ & $2 .(34 \%)$ & $2.7(46 \%)$ \\
\hline scPDSI & GLD & $0.9(15 \%)$ & $3.7(62 \%)$ & $4.2(70 \%)$ \\
\hline scPDSI & GPC & $0.4(7 \%)$ & $2.3(39 \%)$ & $3.2(55 \%)$ \\
\hline scPDSI & TR7 & $0.6(11 \%)$ & $3.1(52 \%)$ & $4.2(71 \%)$ \\
\hline & & $\begin{array}{l}R A<-3 \\
(\mathbf{e x t r e m e )}\end{array}$ & $\begin{array}{l}R A<-2 \\
(\mathbf{s e v e r e})\end{array}$ & $\begin{array}{l}\text { RA } \\
(\mathbf{m o d e r a t e})\end{array}$ \\
\hline RA & CHR & $0.0(0 \%)$ & $0.1(2 \%)$ & $0.5(8 \%)$ \\
\hline RA & CRU & $0.0(0 \%)$ & $0.0(0 \%)$ & $0.3(5 \%)$ \\
\hline RA & ER5 & $0.0(0 \%)$ & $0.0(0 \%)$ & $0.5(9 \%)$ \\
\hline RA & ERI & $0.0(0 \%)$ & $0.0(1 \%)$ & $0.9(15 \%)$ \\
\hline RA & GLD & $0.6(10 \%)$ & $1.8(30 \%)$ & $3.2(54 \%)$ \\
\hline RA & GPC & $0.0(0 \%)$ & $0.0(0 \%)$ & $0.7(12 \%)$ \\
\hline RA & TR7 & $0.0(0 \%)$ & $0.1(1 \%)$ & $0.9(14 \%)$ \\
\hline
\end{tabular}

